\title{
3. Making Featherwork in Early Modern Europe
}

\author{
Stefan Han $\beta$
}

\begin{abstract}
This chapter charts the unknown history of early modern European featherworking and its relationship with the world of matter and making. Focusing on featherworkers' activities in Antwerp, Brussels, Dresden, Leipzig, London, Madrid, Milan, Nuremberg, Paris, Prague, Stuttgart, Turin, and Venice between 1500 and 1800, I study the people, production, networks, materials, techniques, and products of this largely forgotten craft. Over the course of these centuries, artisans developed their initial engagements with feathers from a culture of making to an entrepreneurial culture of decorum. These European artisans' forms of material engagement, I argue, engendered feathers' affective atmospheres. The craft of featherworking affected the material translation of aesthetics since the application of complex techniques helped to perform the material properties of feathers.
\end{abstract}

Keywords: feathers; featherwork; feather-workers; making; material engagement and assemblages; affective artefacts

\section{Craft Expertise and Aesthetics}

Featherwork is widely associated with indigenous cultures. The arrival of New World feathers in late fifteenth-century Europe, however, caused pure excitement across the entire continent. ${ }^{1}$ These feathers' strikingly novel properties - the iridescence,

1 Stefan Hanß, "New World Feathers and the Matter of Early Modern Ingenuity: Digital Microscopes, Period Hands, and Period Eyes," in Ingenuity in the Making: Materials and Technique in Early Modern Europe, ed. Alexander Marr, Richard Oosterhoff, and José Ramón Marcaida (Pittsburgh, PA: Pittsburgh

Burghartz, S., L. Burkart, C. Göttler, U. Rublack, Materialized Identities in Early Modern Culture, 1450-1750: Objects, Affects, Effects. Amsterdam: Amsterdam University Press, 2021 DOI 10.5117/9789463728959_CHO3 
lightness, colour intensity, motility, and gracility of feathers of American species like Amazonian parrots, Mesoamerican resplendent quetzals, and South American hummingbirds - defined their "affective capacities" to stimulate "emotional response(s)." In the "material Renaissance," feathers became highly sought-after products, traded over far-reaching distances and sold in hubs like Seville, Paris, Amsterdam, Venice, or London for the display of refined taste. ${ }^{3}$ During the sixteenth and seventeenth centuries, Europeans were eager to purchase, collect, and store feathers and they invested plenty of energy, money, and time in their transformation. Consequently, European artisans increasingly specialized in featherworking throughout the sixteenth and seventeenth centuries.

This chapter charts the hitherto unknown history of early modern European featherworking and its relationship with the world of matter and making. ${ }^{4}$ Focusing on feather-workers' activities in Antwerp, Brussels, Dresden, Leipzig, London, Madrid, Milan, Nuremberg, Paris, Prague, Stuttgart, Turin, and Venice between 1500 and 1800 , I study the people, production, networks, materials, techniques, and products of this largely forgotten craft. Over the course of these centuries, different products became fashionable. Artisans developed their initial engagements with feathers from a culture of making to an entrepreneurial culture of decorum. Besides hats and panaches, feathers were increasingly attached to all different kinds of things and an astonishing variety of materials became significant for such manufacturing processes. Over the entire early modern period, however, these European artisans' forms of material engagement engendered feathers' affective atmospheres. ${ }^{5}$ I argue that the craft of featherworking affected the material translation of aesthetics since the application of complex techniques helped to perform the material properties of feathers - such as their lightness, translucency, motility, and colourfulness - in culturally appreciated forms. This is what made featherwork matter for early modern materialized identities.

University Press, 2021, in press); Stefan Hanß, “Material Encounters: Knotting Cultures in Early Modern Peru and Spain," The Historical Journal 62, no. 3 (2019): 583-615.

2 Oliver J. T. Harris and Tim F. Sørensen, "Rethinking Emotion and Material Culture," Archaeological Dialogues 17, no. 2 (2010): 146, 150.

3 Ulinka Rublack, "Befeathering the European: The Matter of Feathers in the Material Renaissance," The American Historical Review 126, no. 1 (March 2021): 19-53, https://doi.org/10.1093/ahr/rhaboo6; Stefan Hanß, "The Material Creativity of Affective Artefacts in the Dutch Colonial World: Imaging and Imagining Early Modern Feather Fans," Current Anthropology (in press); Stefan Hanß and Ulinka Rublack, "Knowledge Production, Image Networks, and the Material Significance of Feathers in Late Humanist Heidelberg," Renaissance Quarterly 74, no. 2 (2021): 1-39.

4 Michelle O'Malley and Evelyn S. Welch, eds., The Material Renaissance (Manchester: Manchester University Press, 2007); Pamela H. Smith and Tonny Beentjes, "Nature and Art, Making and Knowing: Reconstructing Sixteenth-Century Life-Casting Techniques," Renaissance Quarterly 63 (Fall 2010): 128-179; Ulinka Rublack, "Matter in the Material Renaissance," Past and Present 219 (2013): 41-85.

5 Andreas Reckwitz, "Affective Spaces: A Praxeological Outlook," Rethinking History 16, no. 2 (2012): $241-258$. 
This chapter reconsiders our understanding of the transformation and challenges of early modern material worlds. Featherworking artisans faced considerable challenges. The special characteristics of feathers caused the high cultural esteem in which sixteenth-century Europeans held this material. These properties, however, also opened a wide range of affordances for the processing of feathers. ${ }^{6}$ At first glance, feathers appear to be easily processable. A closer examination, however, reveals that their material properties gave rise to formidable obstacles. Handling such particularly soft objects was often described in comparison to graceful Renaissance textiles like "deep-napped velvet(s)." ${ }^{7}$ However, precisely this tactile experience relied upon feathers' finely developed barbs, barbules, and hooklets, which were easily damaged by handling and treatments. The iridescence that ensured the vibrancy of the material to Renaissance observers faded when featherwork was exposed to intense light and water. Low room humidity, for example, embrittled feathers. ${ }^{8}$ Their very composition made feathers extremely susceptible to damage. Feathers contain more than 90 percent proteins. This chemical cocktail makes feathers predisposed to damage caused by insects, as the tailor of the southern German court of Württemberg came to realize in 1596. Overseeing the duke's inventory, the tailor came across the miserable appearance of a grey, feather hat. He crossed out the entry and added that "the cockroaches have eaten this." According to an inventory from 1621, the Prague imperial collections' aigrettes were similarly "quite consumed by worms."10

For handling the difficulties and properties of such delicate materials, featherworkers had to master a set of complex skills that aimed to respond to the new "sensory education" caused by, and further promoting, a changing material

6 James J. Gibson, "The Theory of Affordances," in Perceiving, Acting, and Knowing: Toward an Ecological Psychology, ed. Robert E. Shaw (Hillsdale, NJ: Erlbaum, 1977), 127-137; Ann-Sophie Lehmann, "The Matter of the Medium: Some Tools for an Art Theoretical Interpretation of Materials," in The Matter of Art: Materials, Technologies, Meanings, 1200-170o, ed. Christy Anderson, Anne Dunlop, and Pamela H. Smith (Manchester: Manchester University Press, 2014), 21-41.

7 Jean de Léry, History of a Voyage to the Land of Brazil, otherwise called America, trans. Janet Whatley (Berkeley and Los Angeles, CA and Oxford: University of California Press, 1990), 6o. For a broader discussion, see Hanß, "Material Encounters."

8 Chad M. Eliason and Matthew D. Shawkey, "Decreased Hydrophobicity of Iridescent Feathers: A Potential Cost of Shiny Plumage," Journal of Experimental Biology 214 (2011): 2157-2163; C. V. Horie, "Fading of Feathers by Light," in gth Triennial Meeting, Dresden, German Democratic Republic, 26-31 August 199o, ed. International Council of Museums Conservation Committee (Los Angeles, CA: International Council of Museums Conservation Committee, 1990), 431-436.

9 HStAS, A 202, vol. 2394, Nr. 4, 5r; B. S. Harrap and E. F. Woods. "Species Differences in the Proteins of Feathers," Comparative Biochemistry and Physiology 20 (1967): 449-46o.

10 Heinrich Zimmermann, "Das Inventar der Prager Schatz- und Kunstkammer vom 6. Dezember 1621: nach Akten des K. und K. Reichsfinanzarchives in Wien," Kunsthistorische Sammlungen des Allerhöchsten Kaiserhauses 25 (1905): LX. 
environment. ${ }^{11}$ In this chapter, I not only chart the history of early modern European featherworking, I also discuss artisans' proficiency in material transformation and enaction. By studying the feather-workers' dexterity and creativity, I conceptualize early modern featherworking as material engagement embedded in the featherworkshops' material assemblages. Various protagonists engaged with the materiality of feathers to ensure their availability, to craft their shape, and to shape their aesthetics. These artisans' material worlds - their labour organization, manual skills, and artisanal techniques - reveal how knowledge of matter and its transformation lent early modern featherwork cultural significance. On a methodological level, I combine in-depth archival research with an object-centred approach. I relate documents and artefacts with more recent debates on affordances, engagement, assemblage, and affects and thus connect history with archaeology. ${ }^{12}$ By examining the making of affective artefacts, this chapter studies the crafting of early modern materialized identities.

\section{Crafting the Feather Craze}

Johann Wurmbein is one of at least eighteen Nuremberg artisans who manufactured feathers into panaches, crowns, and collars during the sixteenth and seventeenth centuries. The portrait shows his pride to be among craftsmen who mastered materials that had become indispensable items of gallantry (Fig. 3.1). In Paris between around 1500 and 1800 , at least 247 feather-workers sold and advertised a wide range of products including headwear, collars, shoulder and elbow adornments, necklaces, panaches, fans, and shin guards (Fig. 3.2). ${ }^{13}$ Such images reveal the self-understanding of the artisans and similarly "demonstrate the adornment potential" of feathers to clients, pointing to the imagined needs and desired wants that novel commodities like feathers evoked. ${ }^{14}$ "Artifacts act en masse to effect people," and so too did feathers in regard to early modern craftsmen and clients: "groups of related objects [...] create stylistic universes which affect producers and users of new objects, bound by the canons of style." 5 Featherwork

\footnotetext{
11 Beverly Lemire, Global Trade and the Transformation of Consumer Cultures: The Material World Remade, c. 1500-1820 (Cambridge: Cambridge University Press, 2018), 82.

12 Gibson, "Affordances"; Lambros Malafouris, How Things Shape the Mind: A Theory of Material Engagement (Cambridge, MA and London: MIT Press, 2013); Yannis Hamilakis and Andrew M. Jones, "Archaeology and Assemblage," Cambridge Archaeological Journal 27, no. 1 (2017): 77-84.

13 Resulting from my in-depth study of 166 finding aids in the Archives Nationales Paris.

14 Lemire, Global Trade, 79 f.

15 Chris Gosden, "What Do Objects Want?," Journal of Archaeological Method and Theory 12, no. 3 (2005): 193 f.
} 


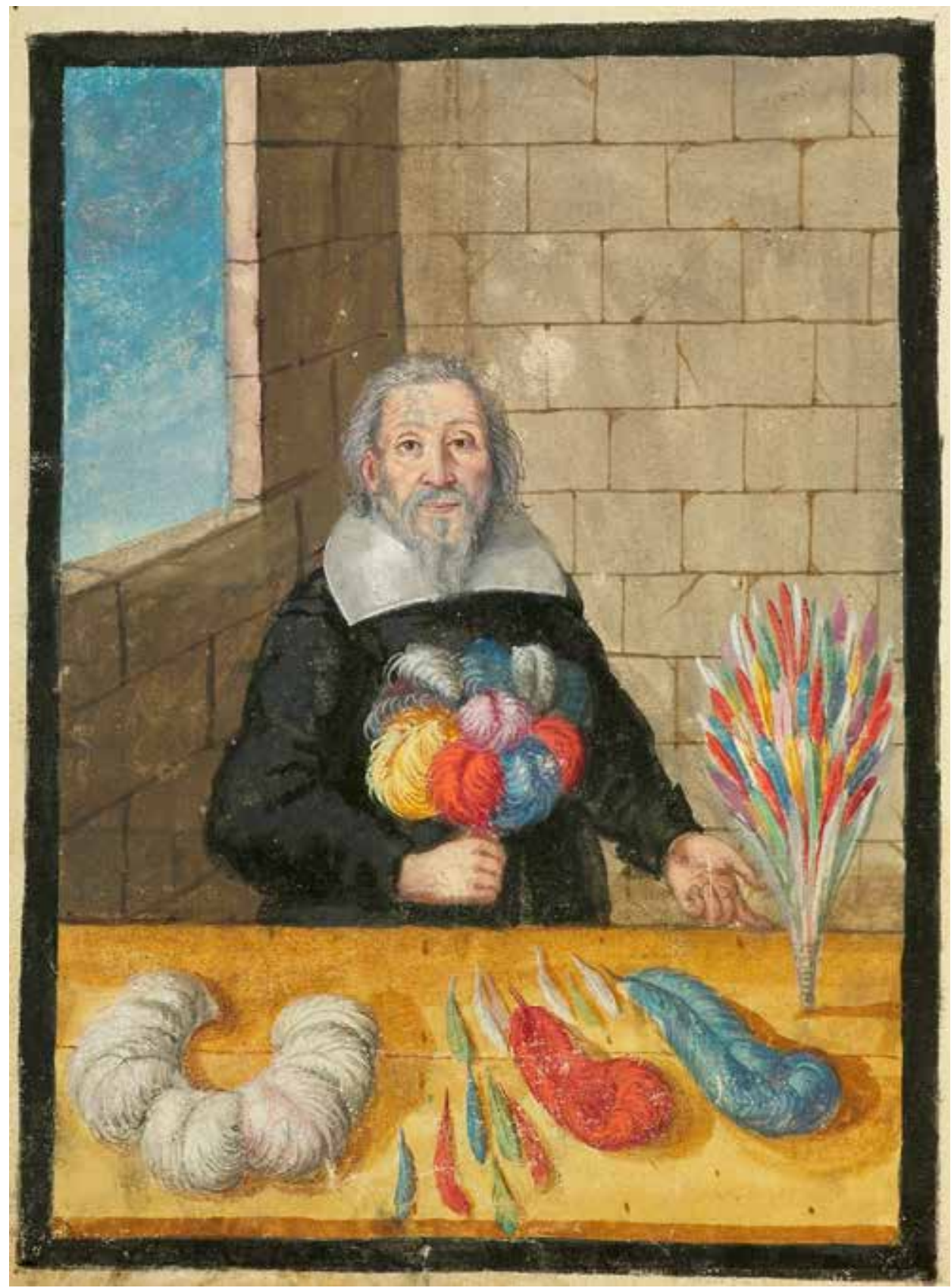

Figure 3.1: Unknown artist, Nuremberg feather-worker Johann Wurmbein. Water colours and tempera on paper, $226 \times 166 \mathrm{~mm}$. In Hausbuch der Mendelschen Zwölfbrüderstiftung, 1667, fol. 151v. Nuremberg, Stadtbibliothek im Bildungscampus Nürnberg, Amb.317b. $2^{\circ}$, f.151v. Image ๑ Stadtbibliothek im Bildungscampus Nürnberg. 


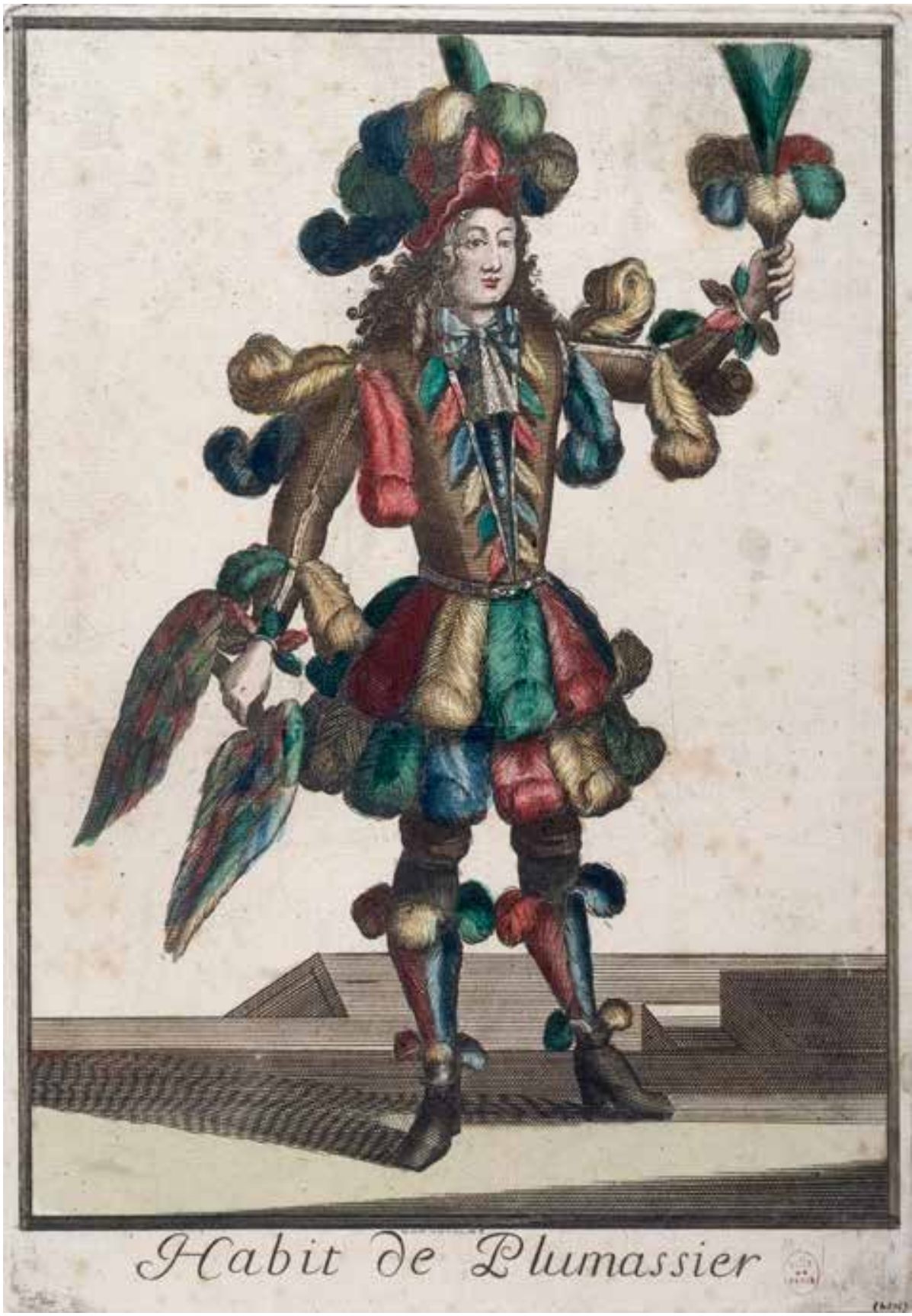

Figure 3.2: Unknown artist (Nicolas de Larmessin II?), French feather-worker advertising his products, after 1695. Print, $277 \times 185$ mm. France, Musée Carnavalet Paris, shelf no. G.5067. Image ๔ Musée Carnavalet / Roger-Viollet. 
also became a catalyst for economic entrepreneurship and engendered cultures of taste. The recent routines of global commerce provided Europeans with access to new materials. Just as Beverly Lemire argued for early modern ribbons, feathers too, belonged among novel "goods essential to this consumerist change providing new sorts of employment and new systems of delight. ${ }^{m 6}$ Feathers inspired the entrepreneurial industriousness that responded to and further generated the demand for desired commodities. An increasing number of protagonists - makers, mercers, and clients - engaged in producing and purchasing the featherwork that transformed material lives in early modern Europe.

Feathers engendered craft professionalization and specialization. Starting at the beginning of the sixteenth century, artisans across Europe began to organize themselves into feather-worker guilds, whose statutes manifested featherworking as a craft bound by rules and a code of honour. In 1530, Brussels feather-workers commissioned their statutes. A "privileged guild" of plumassiers was founded in Antwerp in 1579. Twenty years later, Henry IV issued the statutes of Parisian feather-workers. Elector John George I proclaimed the regulations of Saxonian feather-workers in 1615 . Those regulations of the Nuremberg artisans who specialized in processing feathers were announced nine years later. ${ }^{17}$ Guild statutes shaped the craft's principles, defining its ritual bonds. Leipzig and Dresden feather-workers, for instance, needed to pay regular fees that helped to balance periods of low income. Representatives were elected and met twice a year. Those who wished to become a master feather-worker needed to provide proof of being born in wedlock, having finished one's apprenticeship and afterward travelled in good behaviour, having worked another year with a master after their return, being a local citizen, and having successfully passed the guild's examination, a milestone which was followed by banquets. ${ }^{18}$ Both producing and trading featherwork was restricted to guild members. The rise of Parisian plumassiers, therefore, coincided with the distinction between craftsmen (maittres) and salespersons (marchands). As a widely circulating commodity, feathers and featherwork shaped consumerist desires and caused the fashionability of panaches - a tuft of a varying number of differently manufactured feathers, whose production and trade became the subject of specialized panachemakers (panachers). Those contravening the guild's statutes were severely punished. Parisian plumassiers who employed non-French apprentices had to pay 500 livres to the guild's elders. In 1630, they took proceedings against Pierre Huon, who had

16 Lemire, Global Trade, 79.

17 AVB/ASB, registre n ${ }^{\circ} 3426$; SA, GA\#4254, 7\#1150; Denis Diderot and Jean B. d'Alembert, eds., Encyclopédie ou Dictionnaire raisonné des sciences, des arts et des métiers, vol. 12 (Paris: Samuel Fauche, 1765), 798; August Jegel, ed., Alt-Nürnberger Handwerksrecht und seine Beziehungen zu anderen (Nürnberg-Reichelsdorf: Schmidt, 1965), 511.

18 StadtAL, LXIV Nr. 46, 11r-24v. Special thanks to Bridget Heal. 
sold his featherwork via a marchand bonnetier. ${ }^{19}$ Leipzig feather-workers proceeded against Hans Kolbe, a fellow artisan from Weida, who had asked for citizenship in order to run his own feather-workshop in 1607. Leipzig artisans emphasized that Kolbe was a "blood-foreign" who had engaged in extramarital intercourse "with a foreign and alien maid," his later wife from Glaucha. For the same reason, a similar enquiry in Magdeburg had already failed. Neither becoming a citizen nor having married an honourable burgess excluded young artisans from profits in times of increasing industriousness and competition. ${ }^{20}$

Guild restrictions responded to both the material demands of feathers, which required substantial training, and the high mobility of feather-workers, who needed to have access to the global trade of feathers. Important economic hubs, courts, as well as port and trade fair cities like Antwerp, Brussels, Leipzig, London, Madrid, Nuremberg, Paris, Prague, Seville, and Venice became important sites for feather-workers' activities. The Antwerp feather-merchant Antoine Verra, for instance, regularly travelled to Paris - most likely to buy and sell feathers - and even owned estates en route. ${ }^{21}$ Parisian featherwork-merchant Nicolas Le Trotteur settled in Vienna. ${ }^{22}$ Other Parisian feather-workers formed associations and signed contracts with traders that sold feathers and panaches in Lyon, Reims, and Spain. ${ }^{23}$ Such profit-securing strategies responded to the flows of goods ensuring access to materials, resources, and markets. Turin piumassari had specialized in sending bunches of capon feathers first to Paris and then to Spain and the New World for their suitability as feather dusters. ${ }^{24}$ In 1567 René Guynault, who ran his featherworkshop on the Pont Notre-Dame in Paris, set up a joint venture with the London feather-worker Sébastien Bonnefoy comprising an annual exchange worth 25 écus d'or soleil. ${ }^{25}$ Further names of feather-workers active in early modern England clearly point to their continental background. Henry VIII's feather-worker was called Gerard van Hartell. The name of Edward VI's feather-worker of Saint Peter by Tower, Middlesex, was Paul Vrelande (d. 1551). John Gascarde manufactured feathers in Blackfriars, London, until $1604 \cdot{ }^{26}$ Moreover, Nuremberg's first documented featherprepared by James Worsley in December 1516, edited from Harley MS 2284, and his Inventory prepared on 17 January 1521, edited from Harley MS 4217, both in the British Library (Leeds: Maney, 2007), 334; TNA, PROB 11/34/234; PROB 11/104/348. 
worker Johann Rat, alias Jan de Rat, was presumably from the Low Countries. ${ }^{27}$ Migrating artisans established elaborate networks that connected featherworking hubs, promoting a sense of professional community and advancing the mobility of artisanal knowledge.

The mobility of early modern feather-workers was a vital element of their entrepreneurship. These European artisans' profits relied on their ability to partake in the global trade of feathers - access to such markets and networks defined the success or failure of a person's featherworking business. Nuremberg feather-worker Hans Wollandt, for example, regularly visited Venice to have access to a Mediterranean hub of, and trendsetter in, featherworking. Here, Wollandt also convinced a Venetian shopkeeper to allow him to take care of the latter's adolescent son, Bartholomäus Viatis, who was sent to Nuremberg. In his later autobiographical records, Bartholomäus describes the Nuremberg feather-worker Wollandt as one of the "false hearts" that he had met throughout his life. Despite Wollandt's promise to offer Bartholomäus shelter, clothing, and provisions while training him as an apprentice, Viatis lamented "how hard I was reared in particular by his wife." For three years in a row, the feather-worker apprentice did not drink any beverage other than water. Not even shoes were given to him and frost stigmata covered his thighs still years later. At the end of his apprenticeship, Viatis agreed to serve Wollandt as a business partner in Lyon for another four years, yet Wollandt plunged into debt, ruining the business and the reputation of Viatis. Only in 1565 was Viatis able to break with Wollandt and his co-partners. Four years later, he was granted citizenship in Nuremberg. In his journal, Viatis recorded these biographical hardships for his children's guidance, narrating his story as a feather-worker apprentice who had become a well-to-do merchant and respectable businessman. ${ }^{28}$

This biographical transformation, once again, relied on Viatis's participation in broader commercial networks recorded in his "secret journal." Viatis regularly visited the Frankfurt fair, yet he also maintained close ties with creditors in Bolzano, Venice, and Milan. He joined Daniel Igler's feather-trading business in Milan, until he left for a journey to Wrocław and finally settled in Nuremberg again. Here, Viatis continued to store the financial records that document his commercial ties with merchants, dressmakers, cloth-makers, dyers, and feather-workers in Erfurt, Leipzig, Antwerp, and Italy. Feather-workers Conrath Grisser and Bernhardt Helm,

27 StAN, B14/II Nr. 31, 64r. Rat's support for a brewer from Bruges, who had settled in Nuremberg, further corroborates this observation.

28 StAN, E1/1905, Nr. 1, Jornal vnd Schuldtbu[o]ch of Bartholomäus Viatis (1579), 1r-3v, 6r. Cf. Gerhard Seibold, Die Viatis und Peller: Beiträge zur Geschichte ihrer Handelsgesellschaft (Cologne: Böhlau, 1977). Archival records prove these personal notes' correctness: StadtAN, B14/I, Nr. 90, 35V-38r (1574/o3/og) with reference to the missing folio 220 of StadtAN, B14/III, Nr. 35 . 
for instance, owed Viatis 224 gulden of which to receive he had only "little hope."29 Feather-workers' supra-regional mobility and their far-reaching networks were a vital part of the entrepreneurial strategies that made considerable economic success possible.

The impressive demand for feathers, in fact, allowed highly specialized artisans to make a profitable living. Women, besides men, became successful entrepreneurs. Nuremberg feather-worker Johann Rat's wife, Felicitas, sold a feather beret for 5 gulden 3 pfund and 29 pfennig in $1533 .{ }^{30}$ Two years later, Claude Jablier sold a total of 995 feathers in Paris. Twenty years on, she was still a well-known featherwork trader. ${ }^{11}$ Madames plumassières Denise Feucher and Marie Dangicourt welcomed customers in their early seventeenth-century shops, and Marie Joseph Toutain ran a successful featherwork and fashion shop in the rue Saint-Denis in the 1780 s. $^{32}$ Featherworking, in fact, made entire families prosper. When the Nuremberg house was sold to Rat's five children in 1547 , the dwelling had tripled its value to 1,00o gulden. ${ }^{33}$ Thomas, a son of Rat's first marriage, established his own feather-workshop in $155^{2 .}{ }^{34}$ His brother Anthonius, moreover, maintained business relations with the Negelein, one of the major featherworking families in seventeenth-century Nuremberg: Hans (1572-1641), Adrian (d. 1686), and Johann Stephan (d. 1725/9) were all well-known feather-workers. ${ }^{35}$ In seventeenth-century Paris, the Poirier cousins Jean and Barthélemy as well as André, Claude, Hierosme, Jacques (I and II), Jean, Jérôme, and Pierre Pancatelin dominated the featherworking trade. ${ }^{36}$ Strategic marriages consolidated such well-to-do featherworking dynasties, who established ties with other feather-workers or artisans active in different crafts that were often related to feather-workers' activities. When Hans Negelein died in 1641, his wife Ursula married the "honourable and ingenious feather-decorator Georg Paul Jung." Hanns Maller's widow likewise married another Nuremberg feather-worker, Georg Kramer. ${ }^{37}$ Their workshops, instruments, goods, equipment, and clients made widows, themselves active artisans, a good catch for men aspiring

29 StAN, E1/1905, Nr. 1, 1r-4r, 8v, 41r, 44V, $111 v$.

30 StadtAN, B14/II, Nr. 34, 146v (1533/08/28).

31 AN, MC/ET/III/12 (1535/05/28); Châtelet de Paris, Y//10o, 56v.

32 AN, MC/ET/VIII/564, 6or; MC/ET/VIII/593, 364r; Châtelet de Paris, Y//196, 269r; MC/ET/XXII/52 (1787/07/o9).

33 StadtAN, B14/I, Nr. 194, 56r; B14/I, Nr. 62, 1r.

34 StadtAN, B14/I, Nr. 68, 38 r.

35 StadtAN, B14/II, Nr. 36, 147r; B14/I, Nr. 162, 152r-154r; E8, Nr. 2333/17; E1/1158, Nr. 1, 5rf., 13r; B14/I, Nr. 181, 102v-104r; D1, Nr. 776, Nr. 18; E8, Nr. 2333/14; E8, Nr. 2333/38.

$36 \mathrm{AN}, \mathrm{MC} / \mathrm{ET} / \mathrm{VIII} / 589,234 \mathrm{r} ; \mathrm{MC} / \mathrm{ET} / \mathrm{XI} / 109$, fol. VII/XX/XI; MC/ET/XXIV/342, fol. IIII/C/XXVII; MC/ ET/XXXIV/33 (1624/11/24); MC/ET/XXIV/338, fol. IIII/C/VIII; MC/ET/II/166 (1641/o6/23); MC/ET/CV/587 (1634/02/02).

37 StadtAN, F5, Nr. 3/V, 1592; A1, Schwabach (1598/05/31). 
to commercial and social success. Their privileged positions often resulted in wealth and power. Nuremberg feather-workers Hans Negelein, Mathes Mair, and Georg Paul Jung, for example, served the city's Great Council for five, nine, and seventeen years respectively. ${ }^{38}$

The desire for feather products led to the foundation of numerous shops. In Paris, the Pont Notre-Dame had become the main featherworking address from at least 1540, when Michel David was processing North African ostrich feathers there. ${ }^{39}$ Only forty years later, Hory, Maloiseau, and Noël ran three feather-workshops on that bridge. ${ }^{40}$ Feather-workers like Claude Pancatelin invested highly - 1,0oo livres in 1635 - to install workshops in such vibrant commercial zones, as to do so facilitated access to an ever-increasing number of customers. ${ }^{41}$ In Nuremberg, the Plattenmarkt became a central featherworking venue after Rat established his workshop there in 1508. In 1524, Rat moved into a larger building nearby. Lienhard Moler transferred his workshop from the central market square to the Plattenmarkt in 1548. Hans Wollandt followed in 1555. Nuremberg feather-workshops prospered either in hubs or in short walking distances to areas of public significance like markets or the guildhall. ${ }^{2}$ Municipal and guild regulations tried to manage the urban flows of feathers. Parisian plumassiers ran only one store. ${ }^{43}$ Nuremberg feather-workers were allowed to run either one shop or one market stall; door-to-door selling was explicitly forbidden. ${ }^{44}$ Notwithstanding such regulations, grocers offered feathers of poultry - used to pad blankets - as well as ostrich feathers in local markets, causing "considerable damage" to feather-workers. ${ }^{45}$

Topographies of featherworking were characterized by the remarkable dynamism resulting from the mutual exchanges between urban and courtly milieus. ${ }^{46}$ When

38 StadtAN, GSI152, Obj.Nr. 58.725, 58.870, 59.30o.

39 AN, MC/ET/XXXIII/24, 266v.

40 AN, MC/ET/XXIX/73 (1581/o1/19); MC/ET/LXXXIV/27 (1586/11/14); Châtelet de Paris, Y//127, 370v (1586/02/01).

41 AN, MC/ET/XXIV/342, 427 r.

42 Johann Rat(z) (StadtAN, F5, Nr. 3/I, 2, 1508/og/14; B14/I, Nr. 194, 56r, 1524-1547); Lienhard Moler (B14/I, Nr. 57, 170v, 1544-1548; B14/I, Nr. 62, 108r; E29/I, Nr. 397; F5, Nr. 3/III, 11r-14r, 18r, 1548-1557); Jacob Wasser (B14/I, Nr. 57, 45r, 1545); Hans Wollandt/Bartholomäus Viatis (B14/I, Nr. 71, 11rf.; B14/I, Nr. 90, 35v-38r, 1555-1574); Thomas Ratz (B14/I, Nr. 68, 38r, GNM, Perg.-Urk. 1587/05/05, 1552-1587); Elias Fuchs (StadtAN, E18, U56; U58; U61; U64af., 1568-1573); Hanns Maller (F5, Nr. 3/V, 1592); Georg Kramer (B14/I, Nr. 116, 222v, 1601); Hans Negelein (B14/I, Nr. 133, 246vff., 1621-1548); Georg Paul Jung (B14/I, Nr. 133, 246vff., 1648-1568); Johann Stephan Negelein (B14/I, Nr. 181, 102v-104r, 1684-1686). I could not locate the workshops of Joachim Fehlhorn (StadtAN, E17/II, Nr. 677), Hans Lauff, Mathes Mair, Adrian Negelein, Jacob Stoy, and Johann Wurmbein.

$43 \mathrm{BnF}$, ms. fr. $21798,236 \mathrm{v}$.

44 Jegel, Handwerksrecht, 511.

45 StadtAL, LXIV Nr. 46, 22v; StadtAN, A6, Nr. 691 (1625/06/18).

46 Evelyn Welch, "Art on the Edge: Hair and Hands in Renaissance Italy," Renaissance Studies 23, no. 3 (2009): $260-268$. 
the French royal feather-worker Barthélemy Poirier sold items worth 1,612 livres to François de la Rochefoucauld in 1620, it was the merchant Antoine de Vauconsains who traded the commodities. ${ }^{47}$ By running their own stores in Paris, many of Poirier's colleagues and fellow royal panache-makers, in fact, were in constant touch with urban feather-workers. ${ }^{48}$ The imperial feather-worker Jan Fuchs likewise owned a shop in late-sixteenth-century Prague; he advertised his products by painting the words Perzyssmukyrz and Federschmücker on the wall. ${ }^{49}$ Purchase orders and quittances point to the significance of urban, military, and courtly elites as the driving forces behind the manufacturing of feathers.

Court society, with its demands for splendidly symbolic display, contributed to making featherworking a burgeoning field. ${ }^{\circ}$ On the occasion of the entry of Catherine de' Medici into Paris in 1549, the Duke of Enghien had commissioned his private tailor to buy feathers from Thomas Flache. Building on this reputation, the Parisian artisan worked as the Duke of Nevers's private feather-worker a few years later..$^{1}$ The wedding of Louis XIII and Anne of Austria caused François de Bourbon, cousin of the French king's father, to commission a number of products from two feather-workers at the Pont Notre-Dame, Pierre Clauseau and Germain Hersent: these included twenty-seven large panaches for horses, each of them containing aigrettes and thirty doubled ostrich feathers of red, blue, and white colours decorated with gold wires; another twenty panaches made of nine doubled ostrich feathers; six panaches of four ostrich feathers composed in two layers; and one hundred further aigrettes. ${ }^{52}$ For tournaments held at the Buen Retiro Palace in Madrid in 1633, Felipe Arroyo earned altogether 7,800 reales for manufacturing 1,80o pearl-white and black feathers into twenty-four panaches of different sizes. ${ }^{33}$ Knowing the significance of court festivities for the entire craft, French and German guilds ensured that featherwork would be produced on such occasions and prohibited apprentices to ask for higher salaries. ${ }^{54}$ These examples illustrate how courts stimulated the demand for featherwork, yet they also demonstrate that featherwork became a significant portion of court economies. The southern German court of Württemberg spent 921 florins on the Stuttgart feather-worker

47 AN, MC/ET/VIII/603 (1620/03/o9).

48 AN, MC/ET/II/179 (1646/o3/20); MC/ET/II/183 (1647/04/11); MC/ET/VIII/666 (1649/o8/o8).

49 Pavel Vlček et al., eds., Umělecké památky Prahy, vol. 3 (Prague: Academia, 1999), 207. Warm thanks to Suzanna Ivanič.

$5^{0}$ For a detailed discussion of this in regard to the Spanish court, see Stefan Hanß, "Material CrossReferencing in the Age of Courtly Consumption: Feathers and the Making of Luxury Experiences at the Early Modern Spanish Court" (forthcoming).

51 AN, MC/ET/C/31 (1549/02/13); MC/ET/III/240/A-B (1557/10/10).

$5^{2}$ AN, MC/ET/LXXIII/279, 23 r (1612/03/15).

53 AGP, sección de expedientes personales, caja 151, expediente 7 .

54 BnF, ms. fr. 21798, 233v; StadtAL, LXIV Nr. 46, 17rf. 
Hans Dannenritter on the occasion of the Regensburg Imperial Diet in 1594; a sum that made up almost two-thirds of the court's entire annual expenses spent on textiles. ${ }^{55}$

Manufactured feathers - their colour, quantity, fluffiness, and decoration materialized emotional atmospheres and courtly hierarchies as a court's symbolic language was based on a material vocabulary. To gain proficiency in such a vocabulary, European monarchs employed their own feather-workers, who mastered the material demands and possibilities of feathers. Henry VIII of England commissioned featherwork by his personal plumier. At the Spanish court, royal plumajeros are documented since at least 1564 . French plumassiers $d u$ Roi produced featherwork from as early as $1541 . .^{6}$ Rulers thereby ensured the availability and adequacy of featherwork. In 1564, for instance, Philip II commissioned the royal feather-worker Miguel de Torres to prepare six white and yellow feathers to be given to a recently converted "moor." Three years later, when six indigenous visitors from Florida arrived in Madrid together with a returning Basque man, the plumajero had to manufacture twenty-eight coloured feathers for the decoration of hats. ${ }^{57}$ In France, Louis XIV's ballet performances required feather headwear of outstanding artisanship that aimed both to resonate with the king's movements and to capture the emotional resonances of luminosity and motility..$^{8}$ Appointed as valets de chambre, royal feather-workers' embeddedness within court society enabled them to study the king's body and motions in order to develop appropriate material responses and corresponding artistic techniques. ${ }^{59}$ Such examples vividly illustrate how feathers stimulated systems of labour and styles of fashion as well as how artisans crafted the early modern feather craze.

\section{Material Engagement: Skills and Creativity}

For featherwork to be able to enact affectual spheres to such an astonishing extent, artisans were required to manufacture products that matched potential buyers'

55 HStAS, A 256, vol. 81, 332v-333v. Receipts related to the activities of artisans in Stuttgart will be edited in Stefan Hanß, ed., Court and Material Culture in Early Modern Germany: A Sourcebook on the Duke of Württemberg's Payments to Artisans, Stuttgart, 1592-1628 (Amsterdam: Amsterdam University Press, forthcoming).

56 Hayward, Dress, 334; AGP, Administración General, leg.5.26o, exp.1; AN, MC/ET/XIX/158 (1541/05/18); Hanß, "Material Cross-Referencing."

57 AGP, Administración General, leg.5.26o, exp.1, 1r, 2r.

58 Henri Gissey, Louis XIV in the Guise of Apollo, no date (seventeenth century). Graphite, watercolour, bodycolour, and gold paint on vellum, $304 \times 225 \mathrm{~mm}$, RC, RCIN 913071.

59 AN, MC/ET/VIII/104 (1574/06/05); MC/ET/XXIX/152 (1600/02/21). 
desires. Their capability relied on feather-workers' expertise in acts of material transformation. By engaging with feathers' affordances on a very sensory level, artisans developed crucial cognitive skills in transforming this material. In the words of the French king, the esteem of feather-workers resulted from their manual dexterity, which was capable "to repair the defects of nature" and "to capture the benevolence of the hearts of the most serene highnesses on earth by the work of their [the feather-workers'] hands." ${ }^{60}$ Manufacturing feathers with intricate techniques in order to improve and foreground their material properties, such as the variety and vibrancy of colours or the fluffiness of their appearance, made feather-workers virtuosos in material transformation and presentation. When confronted with what Hernán Cortés described as the natural perfection of New World feathers, the splendour of which had been nowhere-else-seen, ${ }^{61}$ European artisans started to dye feathers of domestic and foreign birds, such as ostrich feathers, by applying intricate techniques. Accepting "the sensorial impact and role of these material things, ${ }^{162}$ means to conceptualize featherworking as acts of material engagement through the study of feather-workers' skills, creativity, and knowledge as a result of extended human-things relationships. ${ }^{63}$

Responding to the intricacy of virtuoso skills for material transformation, guild regulations predominantly addressed questions of apprenticeship. After six years of learning, Parisian apprentices had to craft featherwork in the presence of the guild's most honourable members, who examined the quality of the piece before granting the apprentice the title of a maitre. ${ }^{64}$ In Leipzig, apprentices had to manufacture two different panaches within six weeks - a time span that highlights how time consuming it was to prepare and dry every plume and to sew them together into a panache. The first task was a large panache of twenty feathers dyed in at least three colours with an aigrette at its upper end and three feathers of more than 1 metre in length each tied to the panache's lower end in what was called the "Roman manner." The second panache had to comprise thirty feathers on each side; positioned on its upper end, the panache's three white aigrettes had to be framed by twelve small feathers. In an interim audit, the guild's elders examined the quality of all dyed and processed feathers before allowing the apprentice to

60 BnF, ms. fr. 21798, 238rf.: "reparé les defauts de la nature, captiuer la bienueillance des cœurs des plus grands de la terre, par le trauail de leurs mains."

61 Pascual de Gayangos, ed., Cartas y relaciones de Hernan Cortés al Emperador Carlos V (Paris: Imprenta Central de los Ferro-Carriles, 1866), 101, 109; Alessandra Russo, The Untranslatable Image: A Mestizo History of the Arts in New Spain, 1500-160o (Austin, TX: University of Texas Press, 2014), 20-28.

62 Yannis Hamilakis, Archaeology of the Senses: Human Experience, Memory, and Affect (Cambridge: Cambridge University Press, 2013), 181f.

63 Cf. Hanß, "Material Creativity of Affective Artefacts in the Dutch Colonial World."

64 BnF, ms. fr. 21798, 231r-232v. 
continue manufacturing them into panaches. At least five years of training were needed to master that exam. ${ }^{65}$ In Nuremberg, feather-workers were prohibited to train maidservants and only one apprentice was allowed to be employed for a maximum of five years. Afterwards, artisans had to wait at least one year before hiring a new trainee. ${ }^{66}$

Such regulations framed labour markets by limiting access to profitable businesses, ensuring high prices, and forming artisanal communities. Furthermore, guilds regulated the period an apprentice might spend learning complex techniques. Around 1550, Bartholomäus Viatis still served his master as an apprentice of seven years. His autobiography foregrounds not only his time of hardship, but also his self-awareness of having turned from an apprentice into a virtuous artisan. The feather-worker proudly stated that his apprenticeship served him "to learn to work," ${ }^{67}$ thus, to become proficient in skilled featherworking through repetitive and innovative exercises in material engagement. In the end, Viatis's hands knew what to do: ${ }^{68}$ his featherwork featured the same quality as the products of artisans with an income of 80 gulden. "Without aspiring to fame," Viatis states, "nobody else in this city was able to sew feathers in the same manner except fully [trained] feather-workers." ${ }^{\prime 69}$ In response to the increase of feather-workers, guilds' restrictions also ensured the quality of the crafts as well as its focus on intricate, hands-on knowledge, further promoting a climate of competition and innovation. ${ }^{70}$

Acquiring material proficiencies through sensorial experience and prolonged engagement was crucial for the transformation of feathers into cherished featherwork. Featherworking artisans had to develop skills that relied on tacit knowledge and their amenability towards sensory feedback.${ }^{71}$ Different affordances characterized the various types of feathers of different species, which shaped the possibilities of their manufacture and required different treatments..$^{72}$ Feather-workers, therefore, differentiated between "primary" and "secondary" ostrich feathers according to their age when being plucked. ${ }^{73}$ This coincides with a more general trend of the time: the early modern period experienced an increasing interest in the world's material

65 StadtAL, LXIV Nr. 46, 15rf., 18r-19r.

66 Jegel, Handwerksrecht, 511.

67 StAN, E1/1905, Nr. 1, 1 (1579).

68 David A. Rosenbaum, Knowing Hands: The Cognitive Psychology of Manual Control (Cambridge: Cambridge University Press, 2017).

69 StAN, E1/1905, Nr. 1, 1v.

70 Stephan R. Epstein and Maarten Prak, eds., Guilds, Innovation and the European Economy, 1400-180o (Cambridge: Cambridge University Press, 2009).

71 Malafouris, Things, 79-82, 207-226.

72 Gibson, "Affordances."

Diderot and d'Alembert, Encyclopédie, 12:80o. 
details. Feathers rated among the first objects examined under microscopes. Published in treatises and encyclopaedias, the results of such investigations created further knowledge about the physical composition of feathers and the extent to which details like barbules mattered for the colour, form, and shape of feathers. ${ }^{74}$ For feather-workers, such knowledge manifested in hands-on experience and expertise that, consequently, started to matter to enlightened encyclopaedic enterprises. In order to curl feathers, for instance, artisans had to fix feathers with the left hand while using a special knife (couteau à friser) with the right. The ways in which feather-workers' right thumbs applied fine doses of pressure on the barbs, as we read in encyclopaedias and manuals, defined the feather's shape and quality: only those pieces which required corrections had to be treated, as the entire object's beauty could be easily damaged if too much pressure was applied (Fig. $3 \cdot 3) .^{75}$ The intricacy of this and similar techniques, which required dexterity and malleability of the grip of the hand, often made feather-workers start their six-year-long training in childhood. $7^{6}$

Feather-workers' cognitive world of embodied skills, tacit knowledge, and material proficiency manifests in surviving objects and resonates with sixteenth-century artisanal epistemology's new focus on bodily engagement with nature and matter. ${ }^{77}$ It took years to gain perfection in turning observation into action when processing plumage, since apprentices needed to train their hands and eyes by experimenting with materials and acquiring routines in performing techniques. Artisans had to learn how to sew feathers onto a bonnet with the help of a ribbon and how to fold the starched brim, or to attach a loop, in order to hide the stitches from view (Fig. 3.4)..$^{78}$ Around 1600 , a leather cap was decorated with cords, metal threads, and two cartouches that fixed in place the heraldic emblem and the panache. Starched parchment filled with animal hair and threads built the skeleton of the cartouche, into which feather quills were positioned. Artisans then fixed the panache with three stitches above the cartouche (Fig. 3.5). ${ }^{79}$

Manufacturing feathers of domestic and foreign species meant applying highly intricate and experimental techniques, as Lucas Cranach the Elder's portraits of the

74 Richard Hooke, Micrographia: or some Physiological Descriptions of Minute Bodies made by Magnifying Glasses with Observations and Inquiries thereupon (London: John Martyn, 1665), 167-169, scheme XXII; Diderot and d'Alembert, Encyclopédie, 12:799.

75 Élisabeth-Félice Bayle-Mouillard, Manuel du fleuriste artificiel [...] (Paris: Roret, 1829), $220 f$.

76 AN, MC/ET/III/489 (1610/11/11).

77 Pamela H. Smith, The Body of the Artisan: Art and Experience in the Scientific Revolution (Chicago, IL: University of Chicago Press, 2004).

78 HM, L1435f.; Alheidis von Rohr, “Kleidung eines Patriziers aus Einbeck vom Ende des 16. Jahrhunderts," Waffen- und Kostümkunde 18 (1976): 69-75.

79 GNM, T1593; Jutta Zander-Seidel, ed., In Mode: Kleider und Bilder aus Renaissance und Frühbarock (Nuremberg: Germanisches Nationalmuseum, 2015), 13of. 


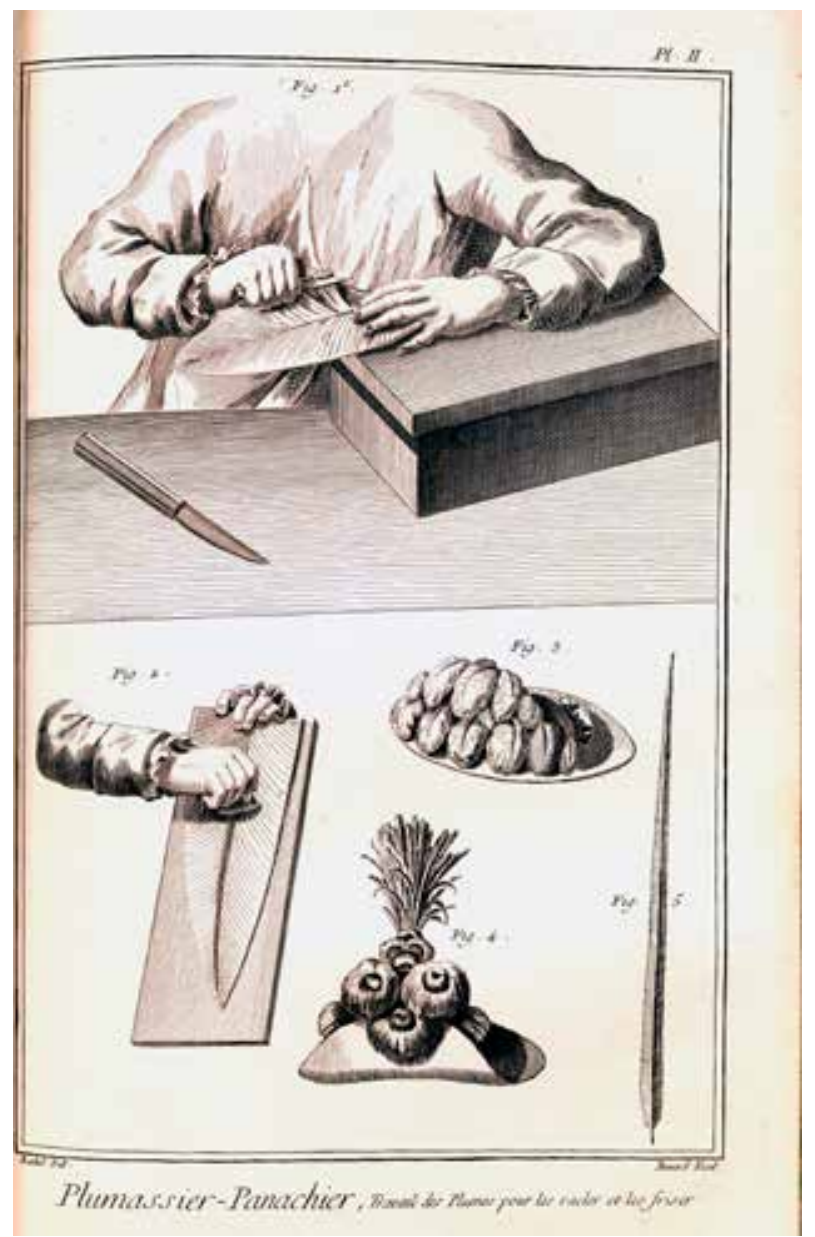

Figure 3.3: Unknown artist, "Plumassier panachier." Engraving, $418 \times 267 \mathrm{~mm}$. In Denis Diderot and Jean-Baptiste le Rond d'Alembert, Encyclopédie, vol. 8, Paris: Briasson etc., 1771, plate II. Cambridge, Library of St John's College, Kk.7.59. Image @ By permission of the Master and Fellows of St John's College, Cambridge.

Elector of Saxony, painted in the 1520s, further demonstrate (Fig. 3.6). To match the entire apparel, feathers could be dyed either in red-gold and dark-silver, or bleached, and each group of barbs were curled. Being decorated with pearls and gold spangles that weighed down their shape granted feathers a dignified resonance when being moved. Such featherworking crafted a material presence that made feathers instantiate splendour. Another telling example is the beret given by Emperor Charles V to Christoph Kress zu Kressenstein, the Nuremberg envoy at the Imperial Diet in Augsburg in 1530 (Fig. 3.7). Artisans stitched the feathers with wires and threads onto the beret. Craftsmen diligently attached twisted metal threads and spangles, 


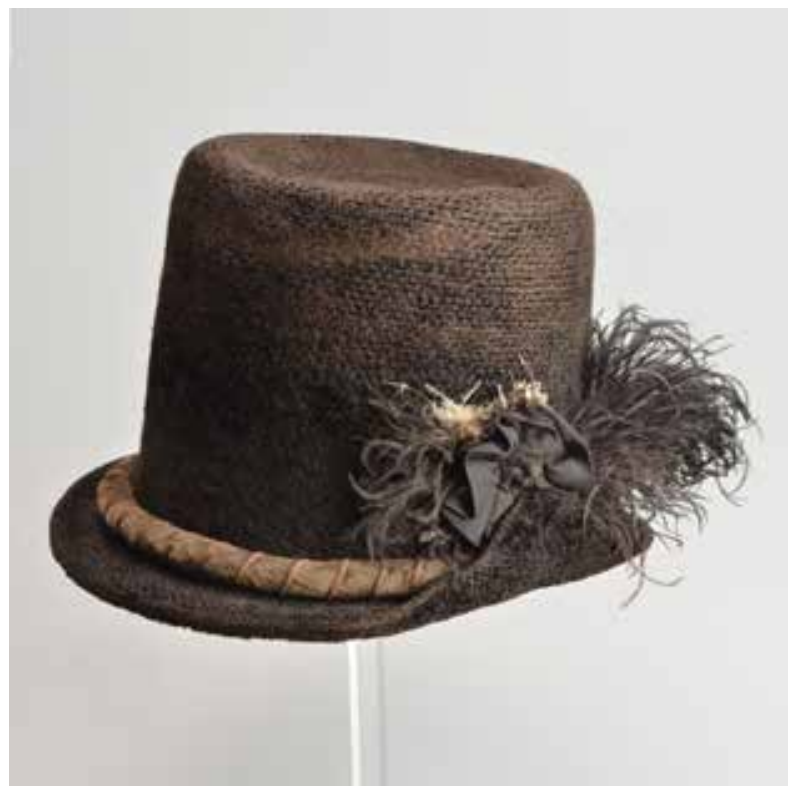

Figure 3.4: German hat with partially destroyed ostrich feathers, late sixteenth century. Felt, woven silk satin, and ostrich feathers, c. $170 \times 290 \times 280$ mm. Hannover, Historisches Museum Hannover, inv. no. L 1436 . Image $\odot$ Historisches Museum Hannover. Photo: Reinhard Gottschalk.

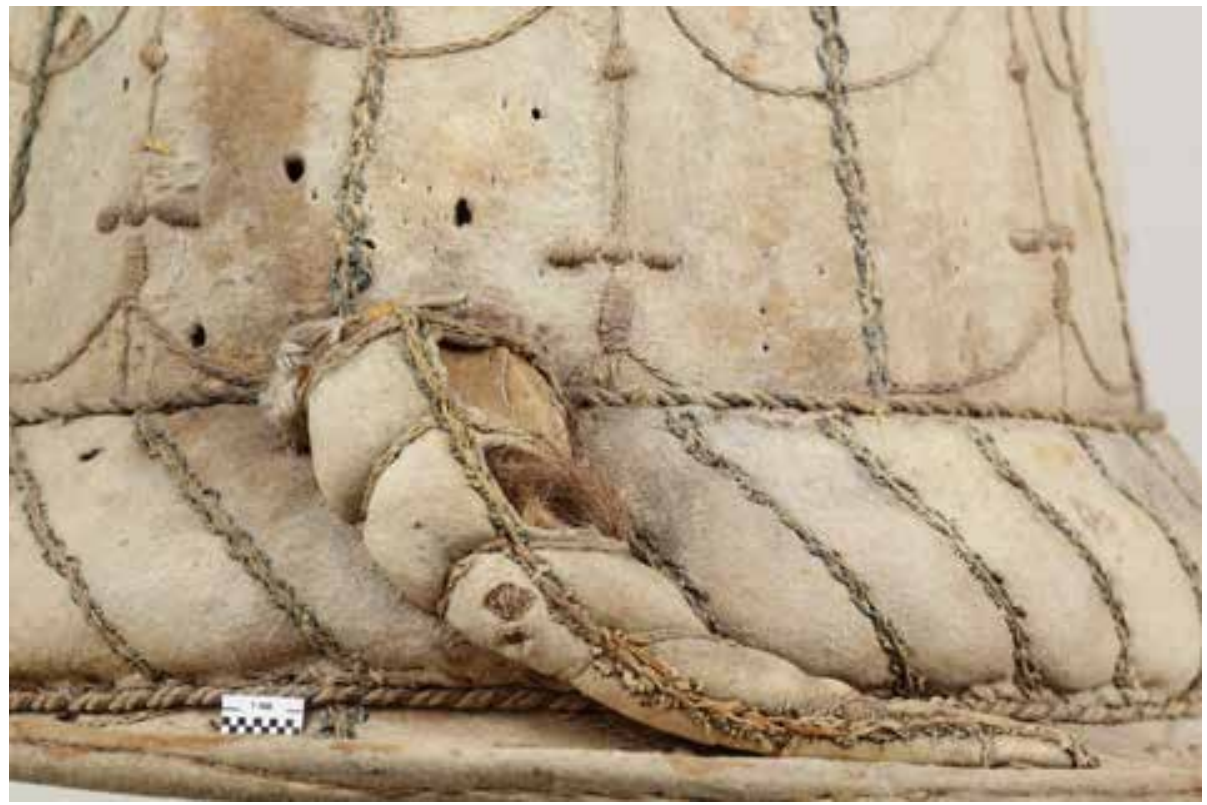

Figure 3.5: Cartouche used to attach panaches onto a leather hat, ca. 1600. Leather, starched parchment, animal hair, and threads, $268 \mathrm{~mm}$ diameter and $190 \mathrm{~mm}$ height of the entire hat. Nuremberg, Germanisches Nationalmuseum, inv. no. T1593. Image @ Germanisches Nationalmuseum, Nürnberg. Photo: Petra Kreß. 


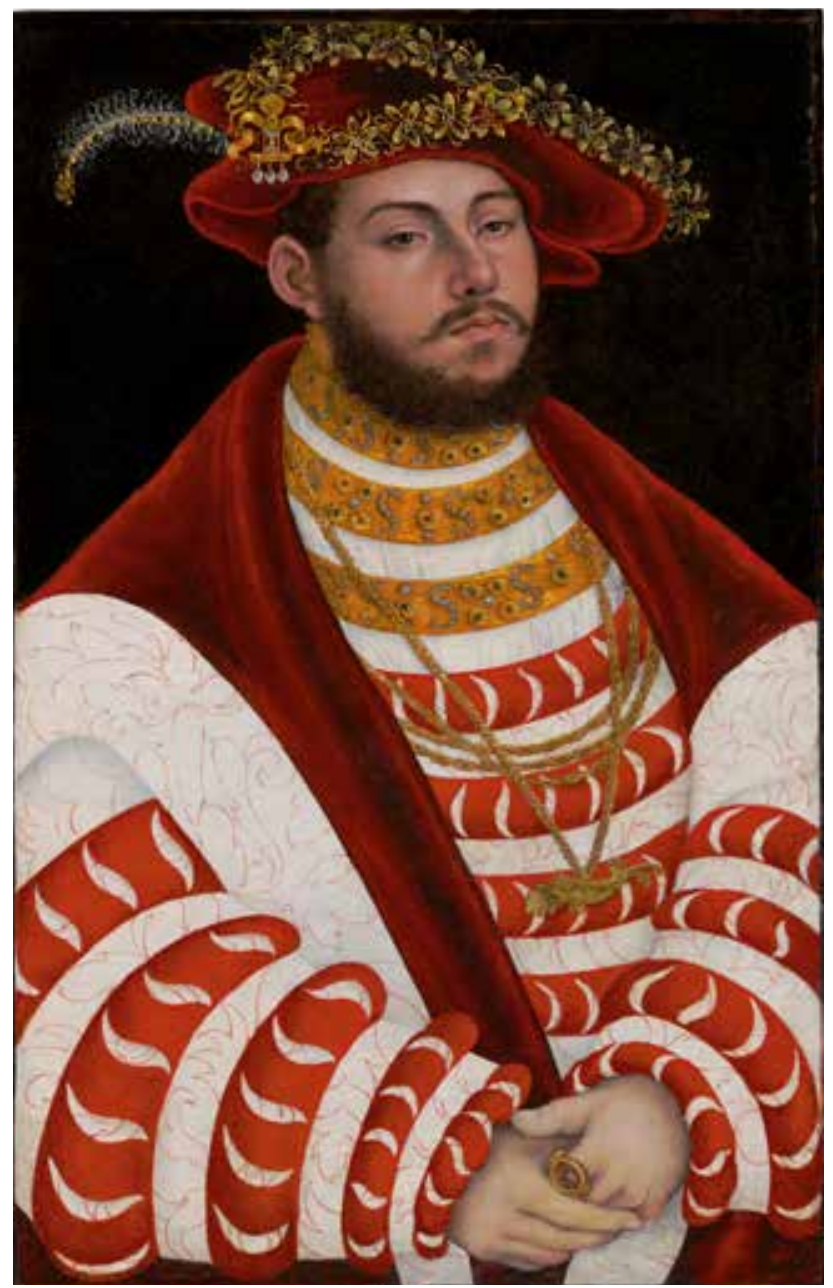

Figure 3.6: Lucas Cranach the Elder, Portrait of John Frederick I, Elector of Saxony, unknown date. Oil on panel, $628 \times 397 \mathrm{~mm}$. Private collection. Image $\odot$ Christie's Images/Bridgeman Images.

punched out of silver gilt, into the feathers to create colour contrasts. ${ }^{80}$ Such objects, as southern German and English documents reveal, often adorned feathers. ${ }^{8}$ After the death of the Württemberg court feather-worker Hans Dannenritter, his widow continued to sell feathers, gold, and silver threads. ${ }^{82}$ Sixteenth-century Augsburg inventories even contain references to Spanish spangles, which were themselves

8 o GNM, T3784; Zander-Seidel, Mode, 4off., 272.

81 Janet Arnold, Queen Elizabeth's Wardrobe Unlock'd: The Inventories of the Wardrobe of Robes prepared in July 1600 [...] (Leeds: British Library, 1988), 201.

82 HStAS, A256 vol. 91, 339r. 


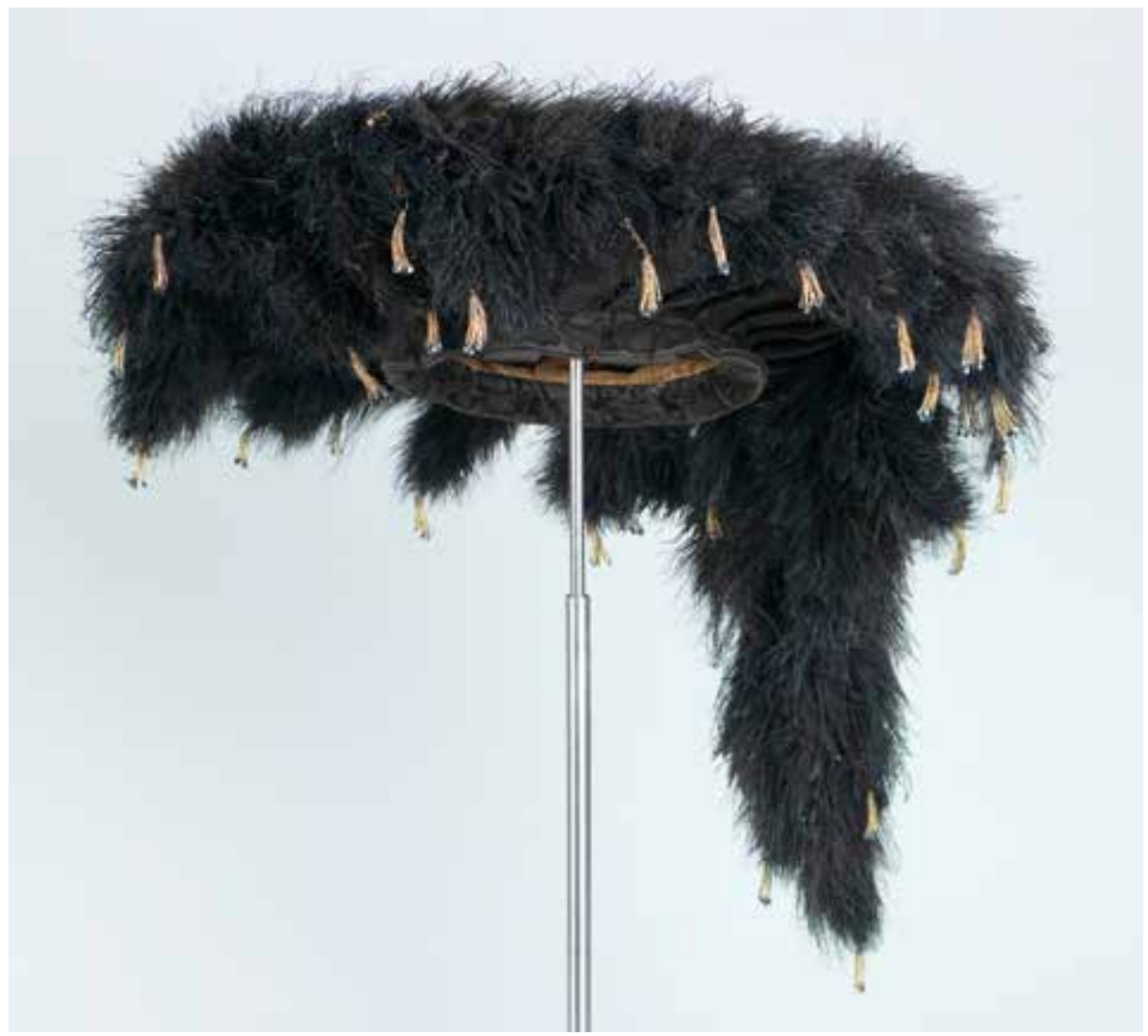

Figure 3.7: The feather-beret of Christoph Kress zu Kressenstein, 1530. Silk satin, ostrich feathers, wires and spangles, $550 \mathrm{~mm}$ diameter. Nuremberg, Germanisches Nationalmuseum, inv. no. T3784. Image $\odot$ Germanisches Nationalmuseum, Nürnberg. Photo: Monika Runge.

"melted like feathers." 83 Two panaches with thirty-six golden spangles cost the substantial amount of 66 gulden in Stuttgart in $1602 .{ }^{84}$

Such innovative acts of creativity, resulting from the artisans' experimental engagement with feathers, served to foreground exactly those properties of featherwork that were held in high esteem. For this reason, feather-workers (Federmacher) became more and more feather-decorators (Federschmücker), whose work was praised for its delicatesse. ${ }^{85}$ Hans Dannenritter, Adam Eßlinger, Wolfgang Wolf, and Jacob Unangst, all courtly feather-workers in Stuttgart, were compensated

83 Norbert Lieb, Octavian Secundus Fugger (1549-160o) und die Kunst (Tübingen: Mohr, 1980), NI209, 325 .

84 HStAS, A256 vol. 89, $382 \mathrm{v}$.

85 BnF, ms. fr. 21798, $229 v$. 
for dyeing feathers and turning them into panaches of either fluffy or pointed appearance. Yet these artisans also manufactured hats; they produced metal threads, sewed garters, and engaged in silk embroidery. ${ }^{86}$ Similarly, Nuremberg feather-workers sold feathers alongside borders and trims. ${ }^{87}$ In the vibrant craft atmosphere of early modern European cities, feather-workers maintained close contacts with jewellers, goldsmiths, wiredrawers, tailors, and clock-makers. ${ }^{88}$ Especially in Paris, feather-workers' experimenting hands established a craft of highly refined and widely purchased luxury products: maitres manufactured feathers into civil and military panaches, headdresses, headwear composed out of several levels, head adornments, hairbows, woven and stitched feather textiles, necklaces, muffs, masks, and garlands, and bouquets of feathers and flowers for men, women, children, horses, and mules alike or as banqueting, altarpiece, funeral, carriage, and street decorations. Peacock feathers were sewn onto garlands. Black fleurs-aigrettes - composed out of cock, raven, and turkey feathers - as well as feathered baldachin decorations staged feelings of sorrow and loss during funerals, while white feathered wings were widely used for performances of angels during processions. ${ }^{89}$ In her shop in the rue Dauphine, Marie Thérese Guerrier sold five muffs made out of black cock feathers for 12 livres and 10 sols; four arrangements of cock feathers to be attached to textiles, meanwhile, cost 48 livres. Besides this, she also owned "three indigenous capes of different colours" as well as chinoiserie vestments. ${ }^{90}$ French artisans produced feather tapestries and decorated entire furniture with feathers. A bed adorned with more than 50,00o feathers of hens, ducks, jays, peacocks, and pheasants, produced by a French feather-worker active in London, was purchased by August II of Saxony in 1723. He then commissioned the bed curtains to be further processed into wall decorations that then decorated the Dresden "feather chamber."91

Being artists in their own right, feather-workers' subtle creativity also attracted the interest of painters. Niklaus Manuel shows how various layers of fluffy ostrich feathers, oversized yet elegantly curled, are fixed to a man's cap (Fig. 3.8). A bell

\footnotetext{
86 Hanß, Court and Material Culture.

87 StadtAN, GSI152, Obj.Nr. 58.725 .

88 StadtAN, E1/1158, Nr. 1, 4rf., 7r, 12r; B14/I, Nr. 181, 102v; B14/I, Nr. 133, 246vff.; B14/II, Nr. 13, 8v; AN, MC/ ET/XXIII/123 (1611/og/o8); MC/ET/XXX/475 (1782/04/o6).

89 BnF, ms. fr. 21798, 23ov; Denis Diderot and Jean B. d'Alembert, eds., Encyclopédie ou Dictionnaire raisonné des sciences, des arts et des métiers, vol. 2 (Paris: Briasson et al., 1751), 366, 626; "Plumassier panachier," Denis Diderot and Jean B. d'Alembert, eds., Encyclopédie ou Dictionnaire raisonné des sciences, des arts et des métiers, vol. 8 (plates) (Paris: Briasson, 1771), pl. IV; AN, MC/ET/XXXIII/24, 266v; Bayle-Mouillard, Manuel, 225.

90 AN, MC/ET/XXVII/457 (1784/03/29), 5r, 6v, $9 \mathrm{v}$.

91 Bayle-Mouillard, Manuel, 228-230; Cornelia Hofmann, Das Federzimmer Augusts des Starken (Dresden: Verlag der Kunst, 2003).
} 


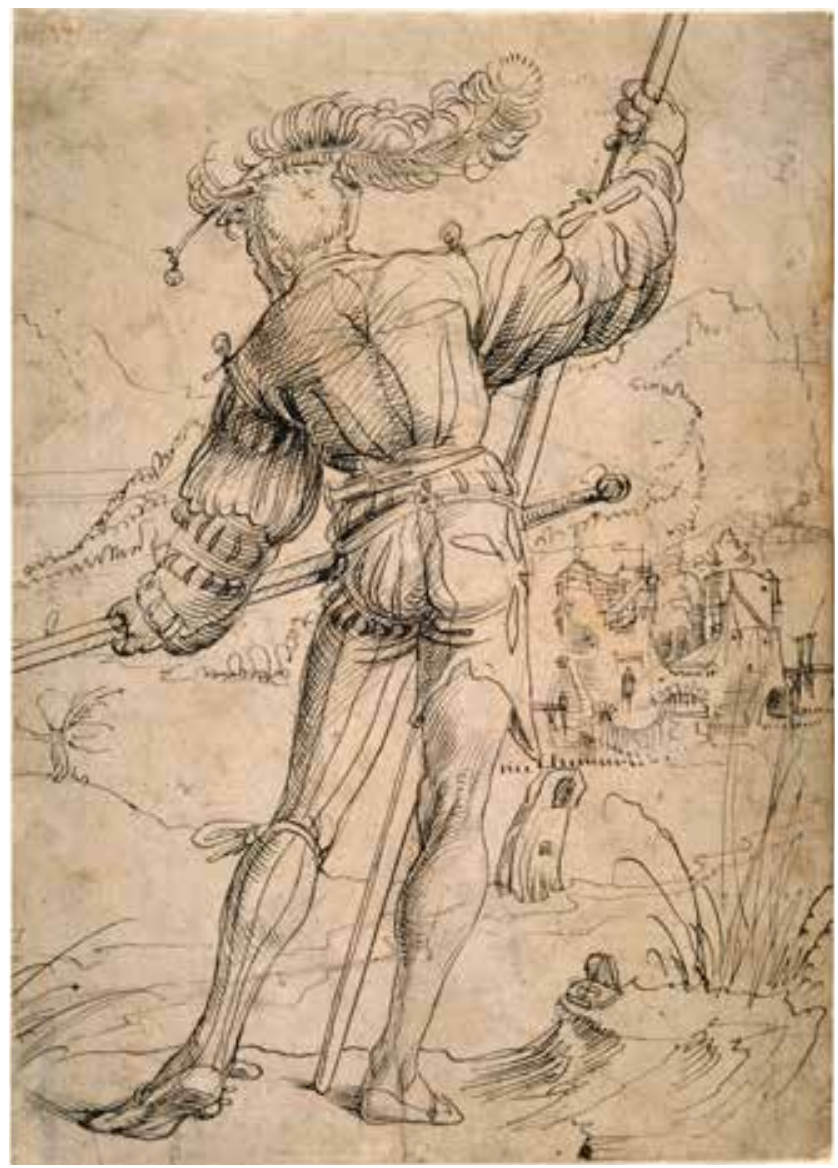

Figure 3.8: Niklaus Manuel, Back View of a Confederate, 1514-1515. Ink drawing, $272 \times 191 \mathrm{~mm}$. Bern, Graphische Sammlung, Kunstmuseum Bern, inv. no. A1979.100. Image @ KMBern.

is tied to the quill as it adorns and balances the construction. Alluding to a fool's jingles, the bell also makes satirical associations. The artisans' skills emphasized the fluffy appearance and elegantly curved motility of feathers, a characteristic that the artist uses to capture the aesthetics of chivalry, gracility, and ease. Given the significance of fashion for the shaping of Renaissance bodies, feathers featured prominently in early modern "polychrome sculpting." ${ }^{22}$ Exuberantly long feathers, for example, heavily affected the performance of postures and gestures. Feathers' delicate appearance not only multiplied gracile movements and the bodily poise, but also demanded a set of certain postures that relied on the body's upright positioning,

92 Ulinka Rublack, "Renaissance Dress, Cultures of Making, and the Period Eye," West 86th: A Journal of Decorative Arts, Design History, and Material Culture 23 (2016): 6-34. 


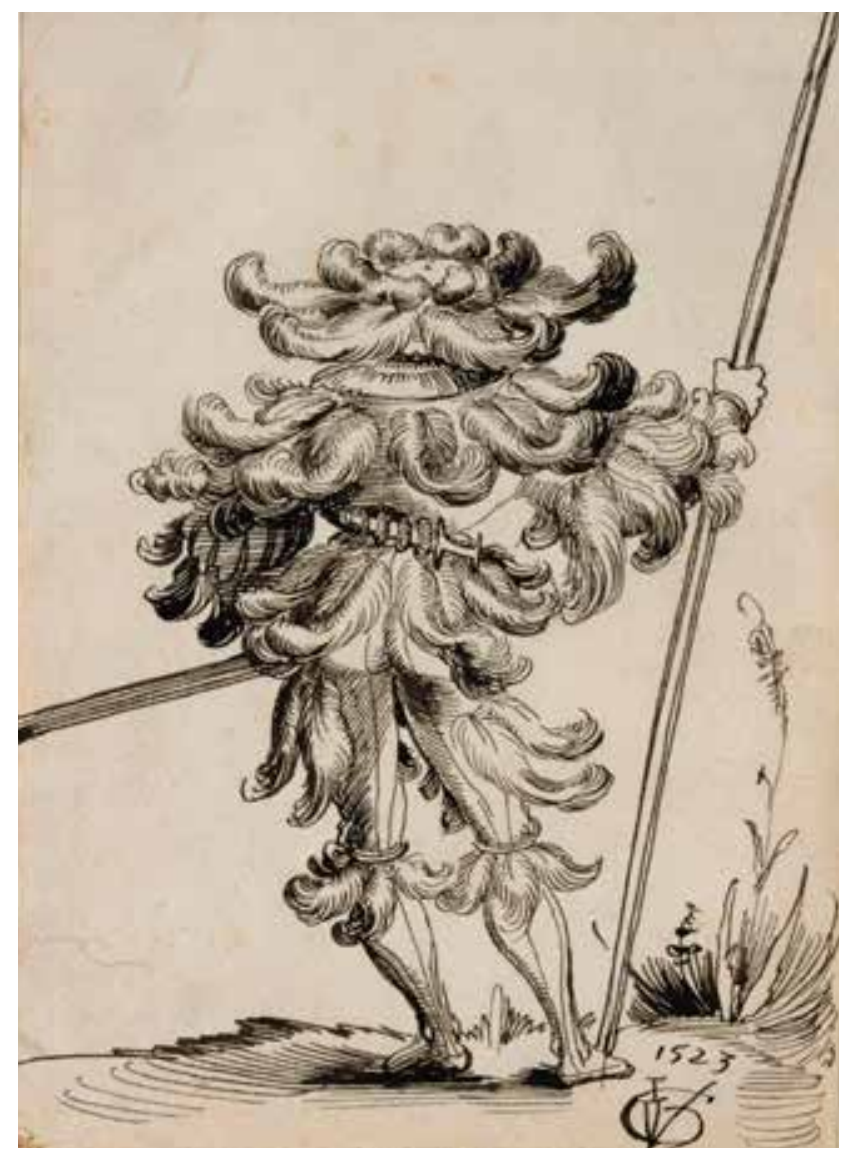

Figure 3.9: Urs Graf, Mercenary's Feather Costume, 1523. Ink drawing, $215 \times 153 \mathrm{~mm}$. Basel, Kunstmuseum Basel, U.X.95. Image @ Bilddaten gemeinfrei Kunstmuseum Basel.

tension, and balance. An awareness for how feathers "would come alive on the body of a wearer through their properties [...] and through movement"93 reveals how materials laboured on and with the body, thereby shaping bodily appearances and aesthetics such as chivalrous or flirtatious registers. ${ }^{94}$ Feather-workers' proficiency in the aesthetic transformation of materials made feathers stage bodily and emotional aesthetics. Artisans and artists were amazed by such transformative acts also visible in mercenary costumes, to whose fabrics, caps, belts, and garters a plethora of feathers could be sewn (Fig. 3.9). Staging luxury as well as haughtiness, pride,

93 Ibid., 7; Denis Bruna, ed., Fashioning the Body: An Intimate History of the Silhouette (New Haven, CT: Yale University Press, 2015).

94 Hans Schäufelein, The Wedding Dancers, ca. 1530 s. Print, $263 \times 214 \mathrm{~mm}$, The British Museum, London (BM), Print \& Drawings, E, 8.114. 
and satire, such virtuoso material and visual performances made featherwork a galanterie, which Augsburg art dealer Philipp Hainhofer, when being placed under house arrest by Swedish troops, was even able to use as a bribe to buy his freedom. ${ }^{95}$

\section{Material Assemblages: (Re)Making Feather-Workshops}

Artisans' workshops (Fig. 3.10) comprised several storerooms with deliberate spatial arrangements. In studios (ateliers) with wooden furniture, tables, candlesticks, sinks, vases, chests, hearths, caldrons, tubs, instruments, and a variety of natural materials, feather-workers manufactured and dyed feathers or worked with flowers. Feathers were stored in caskets, boxes, bunches, and bags in separate rooms (magasins). While a small bunch could contain, as in a couple of cases, 136 or 248 heron feathers, another recorded bunch only stored four male egret feathers; surely this was because of these feathers' particular delicacy, which was the yardstick for their quality and price. If this material characteristic had already been damaged, such garzotti were additionally stored in bunches of hundreds, which facilitated counting. ${ }^{6}$ Account books and manuscripts were kept separately. In the store (boutique), display drawers (étalages) presented the feather pieces and mirrors helped to convince customers to purchase the goods. ${ }^{97}$

Hitherto unknown inventories of feather-workshops in early modern Venice, Paris, and Madrid highlight their character as complex aggregations of materials and things: assemblages that, due "to the vitality of the materialities that constitute it," shaped one's "understandings of life and matter" as much as they engendered craft production. ${ }^{8}$ In such workshops, the artisan's embodied skills met with an assemblage of materials with their own distinct affordances; a productive convergence that shaped both the routines and innovations of feather-workers' material engagement. ${ }^{99}$ The sheer quantity and diversity of feathered products resulting from such acts of material engagement are striking. In 1592 and 1634 , the Venetian stores of

95 SUSBA, $2{ }^{\circ} \operatorname{Cod}$ S68, 6v (1632/04/14); Christoph Emmendörffer, "Wunde Welt: Hainhofers Diarium der schwedischen Besatzung Augsburgs," in Wunderwelt: Der Pommersche Kunstschrank, ed. Christoph Emmendörffer and Christof Trepesch (Berlin and Munich: Deutscher Kunstverlag, 2014), 471.

96 ASVe, Giudici di petizion, inventari di eredità, tutele, curatele, oppure richiesti in causa, b. 36o/25, n. 79 (1647/10/12), 6r; b. 340/5, n. 55 (1591/o1/12 m.v.), 1vf.

97 AN, MC/ET/XCVIII/716; MC/ET/LXXXIV/27 (1585/o2/21); MC/ET/XXVII/457 (1784/o3/2), 3r; MC/ET/ XXIII/477 (1731/06/o9).

98 Hamilakis and Jones, "Archaeology and Assemblage," 81; Jane Bennett, Vibrant Matter: A Political Ecology of Things (Durham, NC and London: Duke University Press, 2010), 34; Beatriz Marín-Aguilera, "Inhabiting Domestic Space: Becoming Different in the Early Iron Age Western Mediterranean," Journal of Mediterranean Archaeology 31, no. 1 (2018): 77-100.

99 Gibson, "Affordances"; Malafouris, Things. 


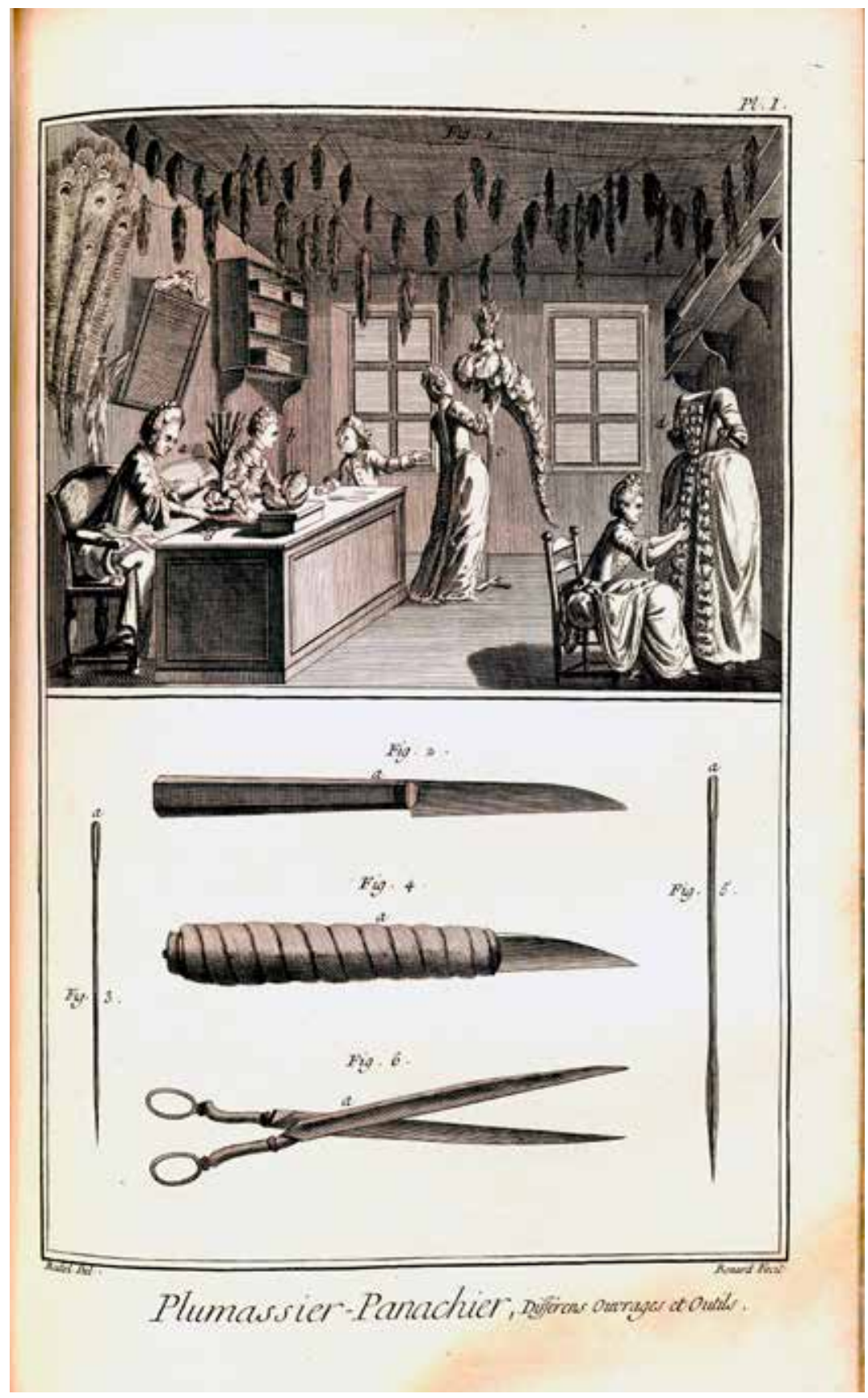

Figure 3.10: Unknown artist, "Plumassier panachier": A Parisian feather-workshop and some of its instruments. Engraving, $418 \times 267$ mm. In Denis Diderot and Jean-Baptiste le Rond d'Alembert, Encyclopédie, vol. 8, Paris: Briasson etc., 1771, plate 1. Cambridge, Library of St John's College, Kk.7.59. Image ® By permission of the Master and Fellows of St John's College, Cambridge. 


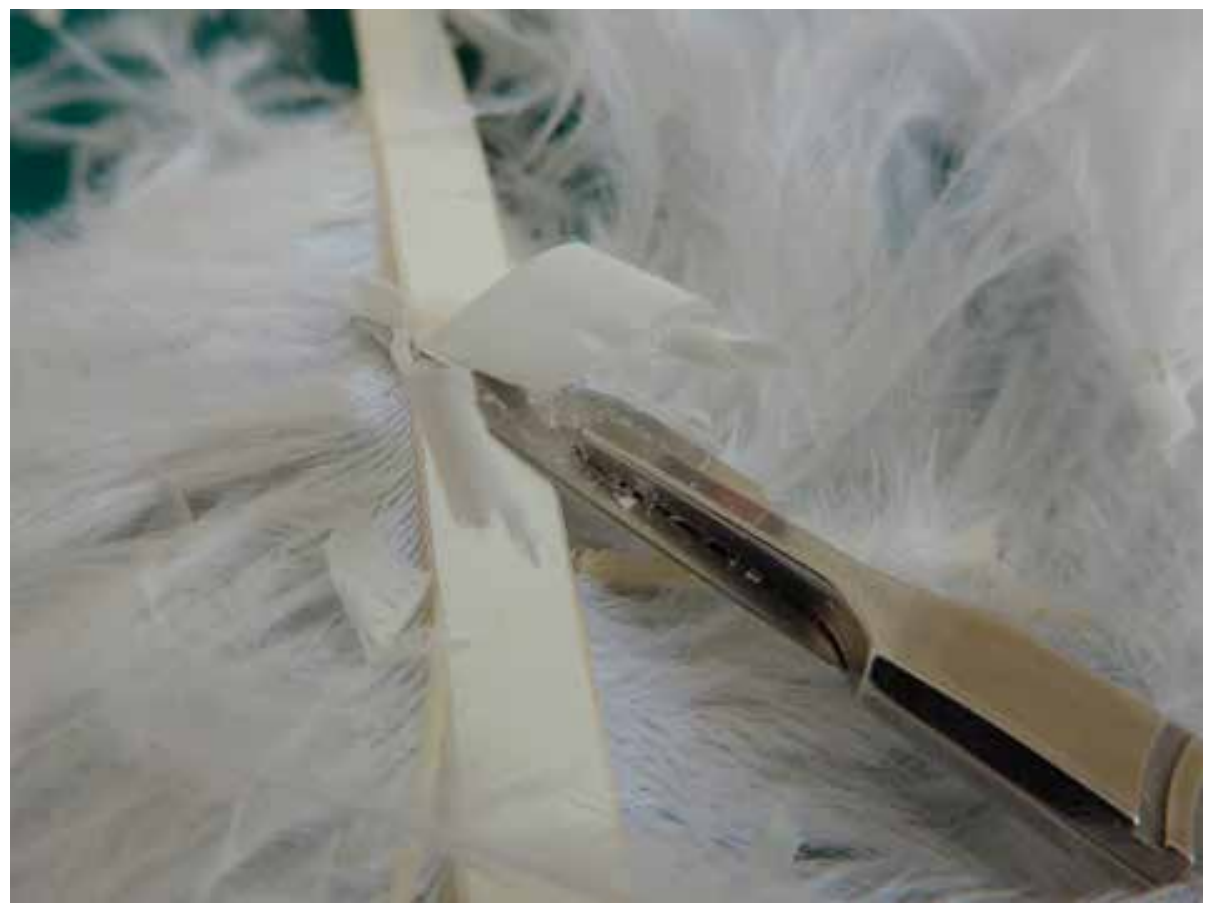

Figure 3.11: Carving ostrich feathers while remaking feather-work at The School of Historical Dress in London. Image ๑ Stefan Hanß.

the pennachieri Giacomo Savioni and Girolamo Zoni held 30,431 and 4,293 feathered items respectively. Near San Salvador, marzer Battista Duceardi offered more than 128,955 feathers and feather products in 1587 . Five minutes away, on the Rialto Bridge, feather-worker Francesco Maselli held 12,375 feather products in $1647{ }^{100}$ Conceptualizing such feather-workshops as assemblages means to examine the actual making of featherwork as an example of processual human-things relationships. The integration of remaking experiments conducted with Jenny Tiramani and Ulinka Rublack at The School of Historical Dress in London on 27 April 2017 helps reconsidering the challenges, demands, constraints, and possibilities of such human-things relationships. Remaking, in this sense, helps unfolding the artisans' sensory engagement with their material surroundings (Figs. 3.11 and 3.12).

Inventories reveal the vibrancy of the trade in domestic and foreign bird feathers, all of them maintaining striking properties: feathers of herons (soft), egrets (delicate, spiky), ostriches (fluffy), swans (white), parrots (colourful), and birds of paradise 


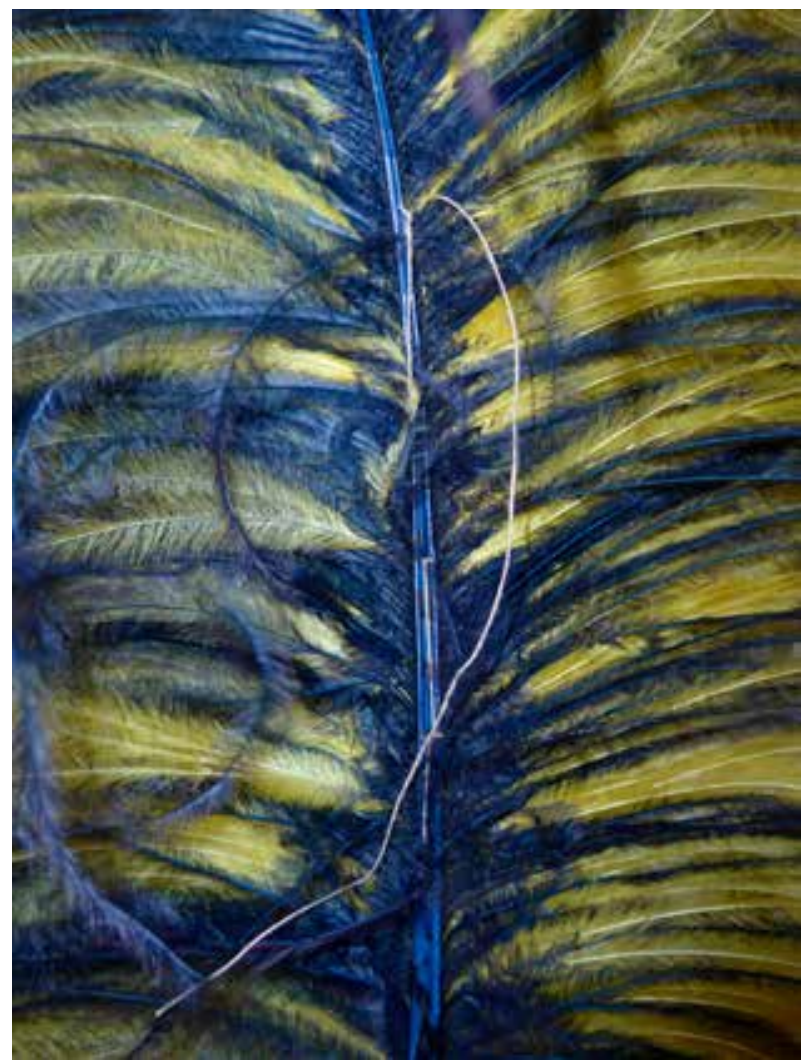

Figure 3.12: Dyed blue and yellow ostrich feathers sewn together at The School of Historical Dress London. Image $\odot$ Stefan Hanß.

(iridescent). Such qualities defined the aesthetic, visual, tactile, and emotional resonances of featherwork and made artisans invest in mercantile networks. Parisian artisans manufactured feathers from the Netherlands and England. ${ }^{101}$ Egyptian herons and North African ostrich feathers had been traded in early modern Venice since at least the late Middle Ages, in fact..$^{102}$ The night heron's white feathers arrived in Madrid from the Spanish Duchy of Milan. ${ }^{103}$ Taxidermy was particularly suitable as this bird's feathers were already cleansed from preen oils. Strikingly colourful American feathers arrived in Seville and were further traded. In Prague, Rudolf II collected not only the feathers of parrots, but also the feathers of swallows and

$101 \mathrm{AN}, \mathrm{MC} / \mathrm{ET} / \mathrm{VIII} / 530$ (1561/11/21); MC/ET/XXVII/457 (1784/03/29), 8v-10r.

102 Nile Green, "Ostrich Eggs and Peacock Feathers: Sacred Objects as Cultural Exchange between Christianity and Islam," Al-Masāq 18 (2006): 27-66; Abraham David, "Jewish Involvement in Ostrich Feathers Trade between Egypt and Venice in the 16th Century as Reflected in Documents from the Cairo Genizah," Judaica: Beiträge zum Verstehen des Judentums 74/1-2 (2018): 82-95. 103 AGP, Administración General, leg.5.260, exp.1 (1584). 
egrets as well as "indigenous red feathers to tie"; that is, Amazonian feathers to be attached to textile pieces like "indigenous caps" and a "feather cape" that were likewise collected. ${ }^{104}$ For purchasing such rarities, the Stuttgart court bought indigenous feather-costumes, parrots, and parrot feathers from the Nuremberg stores of Levin Hulsius and Zacharias Ringsgewanden in 1597/98. ${ }^{105}$ This Württemberg court regularly purchased feathers and featherwork from Nuremberg, but also from Augsburg and Amsterdam. ${ }^{106}$ The grandchild of Nuremberg feather-worker and later successful merchant Bartholomäus Viatis, Johann Andreas (1625-1698), owned "an indigenous dress, studded with rare feathers, and similar caps and shoes" as well as "one still quite well preserved bird-of-paradise."107 Birds of paradise, rare species from the Maluku Islands and the Indonesian archipelago that were also traded by the Venetian feather-worker Maselli in 1647, were imported to the Mediterranean via either the Asian route along the Mughal, Safavid, and Ottoman courts or from the Spanish Philippines via colonial Mexico. ${ }^{108}$ The Leipzig and Frankfurt fairs as well as the activities of journeying peddlers further vitalized the supra-regional flow of feathers, tying dense and vibrant material webs across Europe and the globe. ${ }^{109}$

Plumage of birds of paradise, cranes, and parrots were extremely rare and globally traded commodities, yet the feather craze went along with the rediscovery of domestic aviculture that resulted in a whole specialized branch of the business of fowling that developed dextrous strategies for capturing birds without harming their plumage. ${ }^{110}$ Some Venetian artisans used feathers of the corn bunting and calandra lark as the plumage was characterized by a shiny brown hue, a quality that contemporaries appreciated when studying New World birds. ${ }^{111}$ When estimating the possessions of Savioni in the early 1590s, two fellow feather-workers stated that

104 AGI, Indiferente General, 420, L.8, 6or; Audiencia de Santa Fe, 987, L.2, 14v; Paula Findlen, "Afterword: How (Early Modern) Things Travel," in The Global Lives of Things: The Material Culture of Connections in the Early Modern World, ed. Anne Gerritsen and Giorgio Riello (London: Routledge, 2016), 241-246; Zimmermann, "Inventar," XX, XXXIII, LXf. On taxidermy, cf. Hanß and Rublack, "Knowledge Production." 105 HStAS, A256 vol. 85, 372r, 376vf.

106 HStAS, A256 vol. 85 (1597/98), 378r; A256 vol. 86, 371v; A256 vol. 87, 362r; A256 vol. 93, 364r; A256 vol. 95, 365br; A256 vol. 96, 333v, 337rf.; A256 vol. 97, 338ar.

107 StAN, E1/1905, Nr. 18, 4v.

108 José Ramón Marcaida López, “El ave del paraíso: historia natural y alegoría," in Alegorías: imagen y discurso en la España Moderna, ed. María Tausiet (Madrid: Consejo Superior de Investigaciones Científicas, 2014), 93-108; Claudia Swan, "Exotica on the Move: Birds of Paradise in Early Modern Holland," Art History 38 , no. 4 (2015): 621-635.

109 StadtAL, LXIV Nr. 46, 23r; HStAS, A256 vol. 89, 382v.

110 Giovanni P. Olina, Vccelliera overo discorso della natvra, e proprieta di diversi vccelli [...] (Rome: Andrea Fei, 1622); Hanß and Rublack, "Knowledge Production."

111 Peter Martyr (Pietro Martire d'Anghiera), De Orbe Novo Decades I-VIII, ed. Rosanna Mazzacane and Elisa Magoncalda, 2 vols. (Genoa: Dipartimento di archeologia, filologia classica e loro tradizioni, 2005), IV $9,12-17$. 
Table 3.1: Taxidermies, feathers, and featherwork in the Venetian shops of Battista Duceardi (1587), Giacomo Savioni (1592), Girolamo Zoni (1634), and Francesco Maselli (1647)

\begin{tabular}{lcccc}
\hline feather-related items & Duceardi & Savioni & Zoni & Maselli \\
& $(1587)$ & $(1592)$ & $(1634)$ & $(1647)$ \\
\hline
\end{tabular}

\section{feathers and taxidermy}

heron feathers

black heron feathers

480

heron feathers to be bunched together

heads and necks of herons

2,400

heads of white herons

necks of white herons

300

necks of black herons

black herons, presumably in their entire stature

Egyptian herons

700

5,895

3,200

particularly small feathers of the corn bunting

feathers of the calandra lark

300

2,500

3,800

male egret feathers

dyed male egret feathers

white and dyed male egret feathers

18,600

70,000

200

200

125

crane feathers

170

parrot feathers

feathers of the bird of paradise

processed ostrich feathers

raw, untreated ostrich feathers (pene greze)

black, second-hand

405

in a single layer

1,200

ostrich feathers (pene)

black and white ostrich feathers of small and large

size

black ostrich feathers

black ostrich feathers, to be washed starched black ostrich feathers of small size 


\begin{tabular}{lcr}
\hline feather-related items & $\begin{array}{c}\text { Duceardi } \\
(\mathbf{1 5 8 7})\end{array}$ & $\begin{array}{r}\text { Savioni } \\
\text { (1592) }\end{array}$ \\
\hline $\begin{array}{l}\text { starched black and white ostrich feathers of medium } \\
\text { and large size } \\
\text { black ostrich feathers put aside for a fan }\end{array}$ & 175 & 750 \\
\hline
\end{tabular}

halved ostrich feathers (mezze penne), white or dyed

single ostrich feathers (ugnole/ugniole)

white

white, to be further processed

1,000

black

black, to be washed

dyed

dyed in superior quality

750

dyed in inferior quality

dyed and starched

dyed with spotted surface (so-called pene alla madre, pene machiade, or simply machiadille)

two layers of ostrich feathers sewn together (penne doppie)

single ostrich feathers put aside for sewing

starched and doubled ostrich feathers

dyed and doubled ostrich feathers

dyed and doubled ostrich feathers, to be starched

dyed, starched, and doubled ostrich feathers

dyed, starched, and doubled ostrich feathers in

medium and large sizes

doubled ostrich feathers in small size

doubled ostrich feathers in small size, dyed in various colours

starched and doubled ostrich feathers, black and black

starched and doubled ostrich feathers, black and black, medium-sized and in large size

doubled ostrich feathers, white and black

doubled ostrich feathers, white and white, to be

further processed

doubled ostrich feathers, white and dyed

doubled ostrich feathers, white and red

three layers of ostrich feathers sewn together (penne duppie tre pen[n]e I[']una)

tripled ostrich feathers, dyed in excellent quality tripled ostrich feathers, dyed in inferior quality 


\begin{tabular}{|c|c|c|c|c|}
\hline feather-related items & $\begin{array}{c}\text { Duceardi } \\
\text { (1587) }\end{array}$ & $\begin{array}{c}\text { Savioni } \\
\text { (1592) }\end{array}$ & $\begin{array}{l}\text { Zoni } \\
\text { (1634) }\end{array}$ & $\begin{array}{c}\text { Maselli } \\
\text { (1647) }\end{array}$ \\
\hline \multicolumn{5}{|l|}{ manufactured feathers } \\
\hline \multicolumn{5}{|l|}{ ostrich feathers for women } \\
\hline single layers, dyed & 430 & & & \\
\hline grey & 187 & & & \\
\hline ostrich feathers for esquire & 43 & & & \\
\hline \multicolumn{5}{|l|}{ leaf-like shaped feathers (folle) } \\
\hline in a single layer (folle ugnolle) & 800 & & 500 & \\
\hline in a single layer, black & & 400 & & \\
\hline in a single layer, dyed & & & & 1,800 \\
\hline in a single layer, dyed, to be further processed & 651 & & & \\
\hline doubled (folle doppie), white and dyed & $2,225(+x)$ & & 200 & 700 \\
\hline doubled, black, and dyed & & 2,765 & & \\
\hline spear-like shaped feathers (lanzette), smaller/larger size & 1,350 & & 2,000 & \\
\hline white and silver & 76 & & & \\
\hline white and dyed & & & & 28 \\
\hline starched & 225 & & & \\
\hline with a thimble-like top? (Ianzette dazerali) & & & & 335 \\
\hline \multicolumn{5}{|l|}{ panaches } \\
\hline black panaches & & 125 & & \\
\hline panaches, to be washed & 800 & & & \\
\hline starched panaches & & & 400 & \\
\hline small panaches for peasants & & & 30 & \\
\hline panaches for women, to be washed & 16 & & & \\
\hline panaches of a single layer & & 46 & 200 & 110 \\
\hline panaches of a single layer, white and dyed & 372 & & & \\
\hline panaches of a single layer, dyed and starched & 100 & & & \\
\hline panaches of two layers & 525 & & & \\
\hline panaches of two layers, to be further processed & ca. 300 & & & \\
\hline panaches of two layers, starched, large size & 100 & & & \\
\hline panaches composed out of hundred feathers & & & & 1,400 \\
\hline \multicolumn{5}{|l|}{ top part of feathers (cime) } \\
\hline white and dyed & & & & 1,099 \\
\hline out of a single layer of dyed feathers & & 72 & & \\
\hline doubled & & 675 & & \\
\hline doubled, black & 35 & & & \\
\hline doubled, black, starched & 575 & & & \\
\hline small, white & 236 & & & \\
\hline small, dyed & 300 & & & \\
\hline small, dyed, doubled & 57 & & & \\
\hline not clarified group of objects & 250 & & & \\
\hline
\end{tabular}




\begin{tabular}{|c|c|c|c|c|}
\hline feather-related items & $\begin{array}{l}\text { Duceardi } \\
(1587)\end{array}$ & $\begin{array}{l}\text { Savioni } \\
(1592)\end{array}$ & $\begin{array}{c}\text { Zoni } \\
(1634)\end{array}$ & $\begin{array}{c}\text { Maselli } \\
(1647)\end{array}$ \\
\hline \multicolumn{5}{|l|}{ mattresses (stramazzi) } \\
\hline white & & & & 17 \\
\hline dyed & & & & 16 \\
\hline dyed and small & & & & 15 \\
\hline dyed, medium size & & & & 36 \\
\hline small, dyed in various colours & & & & 56 \\
\hline small, dyed & & & & 30 \\
\hline \multicolumn{5}{|l|}{ caskets with feathers glued onto it } \\
\hline black and white & & & 27 & \\
\hline dyed & & & 50 & 20 \\
\hline separately stored handles & & & & 143 \\
\hline \multicolumn{5}{|l|}{ feather fans (ventagli/ventaggi) } \\
\hline black & 5 & & & \\
\hline white and black & & 1 & & \\
\hline handles for black father fans & 90 & & & \\
\hline old and new white handles made from bone & 23 & & & \\
\hline old and new ivory handles & 12 & & & \\
\hline \multicolumn{5}{|l|}{ small feather fans (ventolline) } \\
\hline produced from dyed male egret feathers & & & & 2 \\
\hline $\begin{array}{l}\text { small feather fans produced from particularly small } \\
\text { feathers }\end{array}$ & & & & 48 \\
\hline dyed/painted (colloratte) & & & 23 & \\
\hline handles for feather fans & & & 24 & 2 \\
\hline \multicolumn{5}{|l|}{ different kinds of feathers stored together } \\
\hline doubled ostrich feathers and panaches, to be starched & & 45 & & \\
\hline feathers from the heron's head and female egret feathers & 150 & & & \\
\hline $\begin{array}{l}\text { doubled ostrich feathers in black and of large size } \\
\text { together with the starched top part of feathers }\end{array}$ & & 200 & & \\
\hline
\end{tabular}

Sources: ASVe, Giudici di petizion, inventari di eredità, tutele, curatele, oppure richiesti in causa, b. 339/4, n. 53; b. 340/5, n. 55; b. 354/19, n. 39; b. 360/25, n. 79.

thirty-six calandra lark feathers corresponded to one ducat and 14 grossi. Seven hundred heron feathers, by comparison, cost 142 ducats. ${ }^{112}$ However, artisans still valued the latter because of their "distinctive structure," which depended on the bird's different types of feathers. Herons' "lanceolate plumes [...] have edges with

112 ASVe, Giudici di petizion, inventari di eredità, tutele, curatele, oppure richiesti in causa, b. 340/5, n. 55, Giacomo Savioni (1591/01/12, m.v.). 
few barbs, giving them a frayed appearance. Aigrettes have long shanks with long elements and minimal barbs, such that they are loose and flexible. Filoplumes are long and hairy."13 Such ornithological peculiarities defined the huge price range of heron feathers and provided artisans with an astonishing material variety to work with; a variety that feather-workers deliberately increased by purchasing an impressive range of flowers. ${ }^{114}$

Feather-workers first washed feathers in hot water with soap. The feathers had to be moved constantly for around five minutes. ${ }^{115}$ For degreasing the feathers of preen oil, they were washed in ash that had been boiled in water and mixed with soap. Again, the feathers had to be constantly stirred. ${ }^{116}$ In a next step, feathers such as ostrich were dyed. Recipes, of course, varied between regions, period, and workshop, and individual expertise affected artisans' choices. According to sixteenth-century Venetian recipes, feather-workers used ash, metal salts, and dyestuffs to achieve specific colours. ${ }^{117}$ Eighteenth-century Parisian recipes document correspondingly sophisticated knowledge. For whitening, feathers were washed in chalk. Indigo and azure pigments served as blue dyestuffs that were mixed in large quantities with cold water. Wood and ferrous sulphate helped feathers to take on a deep black, while acid and ammonium salt or indigo turned feathers green. For purple dyeing, feathers were prepared with alum before being dyed in a very hot water and brazilwood mix for several hours. The very same ingredients mixed together made feathers appear red after half a day of treatment. Pale pink was achieved with saffron and cold lemon squash; yellow with saffron and alum. To dye feathers orange, the seeds of the American achiote flower were boiled in the water into which the feathers were soaked as soon as the liquid had cooled off. ${ }^{118}$ French inventories of the same decades contain references to copper green, yellow, alum, and blue vitriol dyestuff. Above all, their descriptions illustrate the material surrounding of such complex procedures: in her Parisian feather-workshop in 1784, Marie Thérese Guerrier used, for the dyeing and washing of feathers, "a large copper tub in red [...], another large copper tub in yellow [...], two small copper tubs in red, two kettles with copper handles in red, a big copper kettle in yellow, a medium copper kettle in yellow, two small copper caldrons in yellow, [and] a copper pot for red-washing" worth 140 livres. ${ }^{119}$ The availability of such objects and obstinacy of the materials they

113 James A. Kushlan and James A. Hancock, The Herons (Oxford: Oxford University Press, 2005), 8.

114 In late eighteenth-century Paris, aigrettes cost between 1, 2 and 80 livres. AN, MC/ET/XXVII/457 (1784/03/29), 9v; MC/ET/XCVIII/716 (1797), 18v-25r (here 20v); MC/ET/LXXXIV/27 (1586/11/14).

115 Bayle-Mouillard, Manuel, 213 f.

116 Ibid., 216.

117 Rublack, "Befeathering the European."

118 Bayle-Mouillard, Manuel, 214-218.

119 AN, MC/ET/XCVIII/716 (1797), 25rf.; MC/ET/XXVII/457 (1784/o3/29), 1or. 
processed challenged and defined artisanal work. It needed financial investment in materials as well as considerable training to know the correct temperatures for boiling water and the right moment to stop treatments. In order to match buyers' different aesthetic interests and financial circumstances, feather-workers dyed feathers in superior and inferior qualities. Even spotted surfaces were sometimes achieved.

To accomplish the softness and fluffy volume of feathers after such intense treatment, it was crucial to reshape the structure of the barbs and barbules. The often axial arrangement of windows in Nuremberg feather-workshops ensured the constant air flow that was required to dry the washed feathers when put on the line. French feather-workers also dried feathers under the sun or under low temperature in a drying closet (étuve). Artisans then beat them upon a table and rearranged the barbs by hand. A female feather-worker in eighteenth-century France applied yet another time-consuming drying technique. She impaled feathers on toothpicks and arranged them on a green in such a manner that they were exposed to a constant circulation of air. After a period of fifteen days, air and condensation restored the feathers to their full beauty. ${ }^{120}$ Such intricate techniques made feathers precious commodities. In Madrid, even a "simple" black or white ostrich feather cost $3^{1 / 2}$ reales in 1564 . A single heron feather in white, yellow, or purple cost 2 reales twenty years later. ${ }^{121}$ Such prices - found all over Europe - rendered it worthy to re-engage with already used feathers. In French workshops, for instance, used feathers were boiled in bunches, sulphurized, dyed anew, and treated with heat, hands, and scissors before being sold again. ${ }^{122}$

Artisans further processed feathers by cutting them in the form of leaves and small spears. Venetian inventories labelled these products folle and lanzette; in Stuttgart, the latter were called Spitzfedern. ${ }^{123}$ Both types of processed feathers were either sold or used for further manufacturing. Sometimes, the full and fluffy top parts of ostrich feathers were cut off and sold as cime or cimette, which could easily be attached to caps. Ostrich feathers were starched, sliced into two halves along the shaft, and sewn together according to different sizes, shapes, and colours. For such manufacturing, feather-workers needed to be skilled and patient in needlework and in the use of sharp knives (cf. Fig. 3.11). In Stuttgart in 1621, a Federmeßerlin - maybe used for cutting quills for writing - cost the considerable sum of 4 gulden. A Prague inventory of the same year mentions that Rudolf II had collected "Ottoman feather knives." ${ }^{24}$ Handling the knives used to manufacture feathers was definitely not easy, although we have to bear in mind that feather-workers lived in a milieu in which the careful cutting

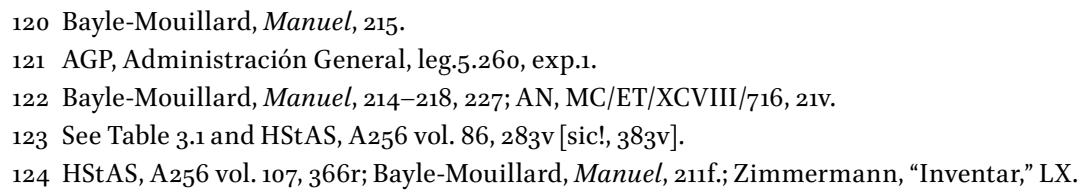


of quills was an indispensable skill for scribes and artists. ${ }^{125}$ Sewing the feathers together in two, three, or even more layers was similarly demanding due to the shaft's hard composition (cf. Fig. 3.12). Such doubled feathers (plumes doubles) seem to have been particularly popular. ${ }^{126}$ Feather-workers then bent and curled feathers using irons and also applied gold leaf and jewellery. ${ }^{127}$ In 1577 , the Nuremberger Wolfgang Münzer owned black, white, yellow, and red ostrich feathers, all "looped with gold (wire)" along their spines. Furthermore, he possessed three "adorned" parrot feathers and another three crane feathers "decorated with gold" - here, the metal threads interacted with the metallic iridescence of the feathers of certain parrots. ${ }^{128}$ According to their characteristics and treatment, feathers were then processed into a large variety of products such as (starched) panaches or spear-like lanzette, which were themselves often doubled and starched in order to achieve a particular material stiffness. Inventories also mention caskets with feathers glued onto them. Similar leather caskets with decorative motifs, often showing New World birds stitched onto them, are also preserved from the colonial Americas. ${ }^{129}$ Hence, it seems reasonable to assume that Venetian feather-workers' caskets could have been adorned with precious feathers of rare avian species that themselves evoked associations of the wider world. All these different kinds of treatments defined how feathers might have been used, to which purpose, and whether by men or women. Feather-workers' material knowledge, creativity, and dexterity, above all, helped feathers to stage their properties in ways that clients appreciated so much.

\section{Affective Fields: Panaches and Fans}

The inventories also point to the significance of panaches and feather fans - telling examples for the discussion of how makers' skills in material transformation attended to objects' sensorial properties. Discussing the relationship between things and emotions, archaeologists have developed the concept of "affective fields": humanthings relationships that stimulate emotional responses; emotions being defined "as the act of being moved [...] tied to [...] the perception of particular bodily states." ${ }^{\prime 130}$

125 Cennino d'Andrea Cennini, "Il Libro dell'Arte": The Craftman's Handbook, trans. Daniel V. Thompson Jr. (New York: Dover, 2016), 8; Wolfgang Fugger, Ein nutzlich vnd wolgegrundt Formular, Manncherleÿ scho[e]ner schriefften [...] (Nuremberg: Valentin Geißler, 1553), bijr.

126 AN, MC/ET/III/308 (1558/01/28).

127 Ibid.

128 Jutta Zander-Seidel, Textiler Hausrat: Kleidung und Haustextilien in Nürnberg von 1500-1650 (Munich: Deutscher Kunstverlag, 1990), 226.

129 Museu de l'Art de la Pell, Vic (MAP), no shelfmark, cistella (seventeenth-century Mexico).

130 Harris and Sørensen, "Rethinking," 149-153. 
Following this line of enquiry, it is important to examine how artisans' handgrips affected the sensory experience of handling objects. In the case of panaches - a very specific and extremely popular product of European featherworking - the hands of the makers met those of the users. While artisans' hands shaped the motility of feathers, the hands of clients arranged the artefact for the movements of bodies and their capacity to move other people. Feather-workers' abilities in making crafted the conditions for sensorial engagements with materials: artisans helped featherwork to attract the senses and to establish affective resonances.

Early modern featherworking is characterized by an increasingly intricate tradition of panache-making. Consequently, panaches became associated with local fashion styles and featured prominently in sixteenth-century costume books' representations of the sartorial appearances of women from different regions. ${ }^{131}$ Such prints helped to make panaches fashionable, identificatory items whose styles began to travel. Spanish-style panaches became en vogue in sixteenth-century Paris. In his shop on the Pont Notre-Dame, Jehan Maloiseau sold "a large Spanish-style panache" for 48 sols in 1586 . By comparison, customers had to pay 20 sols for four black panaches and only 15 sols for a bundle of "nine small panaches."132 Even in seventeenth-century Peru, Castilian feather panaches were precious luxury items used by mestizos. ${ }^{133}$ The appreciation of Spanish-style panaches resulted from their decorativeness. In 1584, a Madrid feather-worker manufactured a total of forty-eight feathers into panaches that cost 6 reales. Panaches composed out of altogether twelve violet, yellow, and white feathers cost 8 reales. Similarly costly was a panache made out of fourteen feathers dyed in white, yellowish-green, brown, and intense red. ${ }^{134}$ Fashion trends, of course, changed and are hard to specify - in eighteenth-century Paris, Russian panaches had become fashionable ${ }^{135}$ - yet a rich and diverse engagement with panache-making was a general trend in early modern featherworking. Jean-Marie Aubertin even offered panaches de fantaisie for sale in late eighteenth-century Paris. ${ }^{136}$

Evolving from this intricate tradition of panache-making, fans engendered people's fantasies. Queen Elizabeth I consciously staged feather fans as artefacts of royal splendour. Portraits show the monarch handling a panache composed out of dozens of intensely dyed, small ostrich feathers. A few years later, Elizabeth

131 Hans Weigel, Habitus prcecipvorvm popvlorum [...] (Nuremberg: Hans Weigel, 1577), CXXIIIIf., CXXXIIII, CXLVf., CXLVIII; Jost Amman, Gynceceum, siue theatrvm mvliervm [...] (Frankfurt: Sigmund Feyerabend, 1586).

132 AN, MC/ET/LXXXIV/27 (1586/11/14), 5r-6r.

133 Hanß, "Material Encounters," 601.

134 AGP, Administración General, leg.5.260, exp.1 (1584).

135 Bayle-Mouillard, Manuel, 226.

$136 \mathrm{AN}, \mathrm{MC} / \mathrm{ET} / \mathrm{XCVIII} / 716,2 \mathrm{ov}$. 


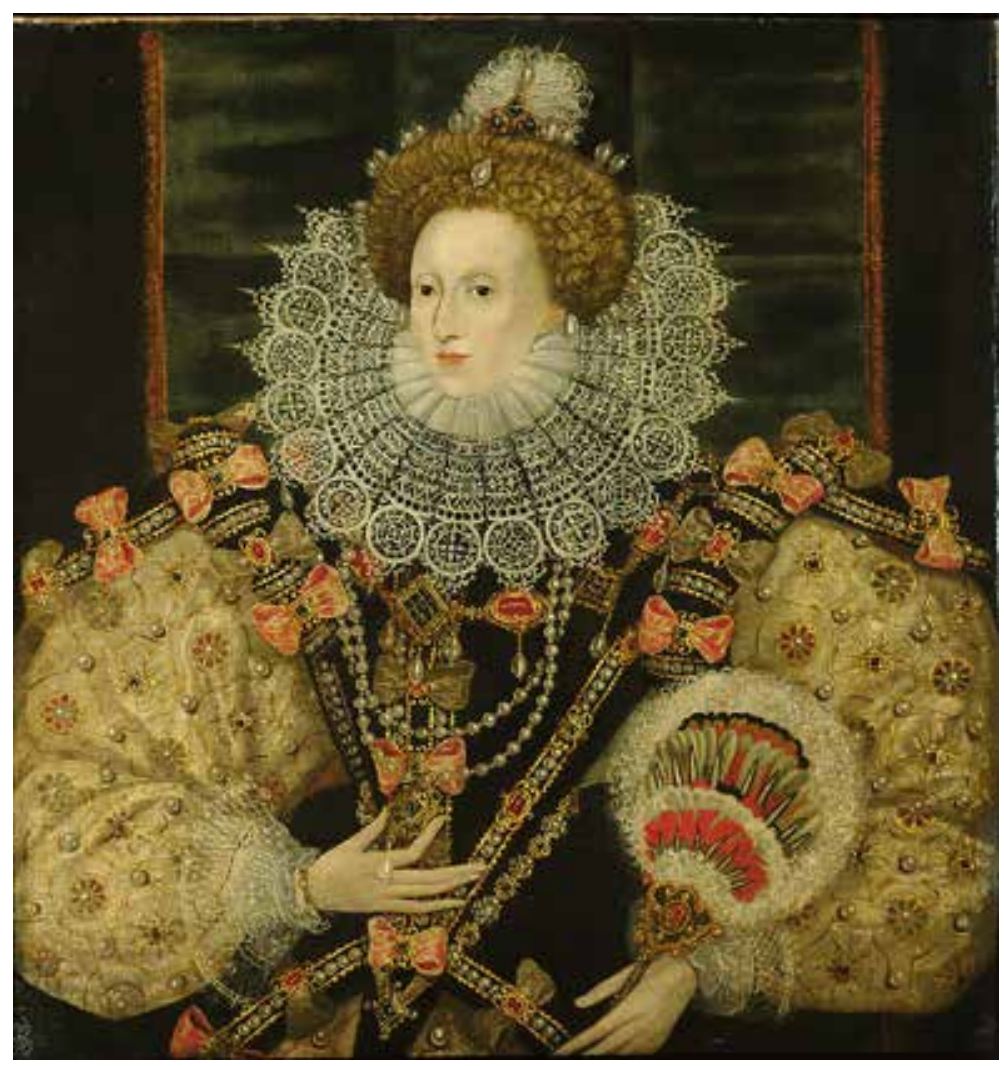

Figure 3.13: George Gower, Queen Elizabeth I, ca. 1588. Oil on canvas, $1010 \times 978 \mathrm{~mm}$. The Leicester Galleries, no signature. Image $\odot$ The Leicester Galleries.

used fans manufactured from astonishingly large, bowed ostrich feathers. ${ }^{137}$ According to inventories, the monarch owned fans composed out of tawny, straw-colour, carnation, white, and ashen feathers. The handles were made from bone, ivory, silver, and gold and were set with pearls and jewels. For preserving the integrity of such precious items, feather fans were stored in separate boxes wrapped in leather, taffeta, and paper. ${ }^{138}$ Both feather-workers and painters clearly tried to capture these material interplays, establishing affective atmospheres.

Jewellery applications and colour arrangements made feather fans crucial elements of splendid apparels, a visual tradition that culminates in a slightly later portrait showing Elizabeth handling a fan composed with colourful Amazonian feathers framed by curled ostrich feathers traded via North Africa (Fig. 3.13). As

137 Anonymous, Queen Elizabeth I, ca. 1575, National Portrait Gallery, London (NPG), NPG 2082; Anonymous, Queen Elizabeth I, ca. 1585-1590, NPG 2471.

138 Arnold, Wardrobe, 230, 349f. 


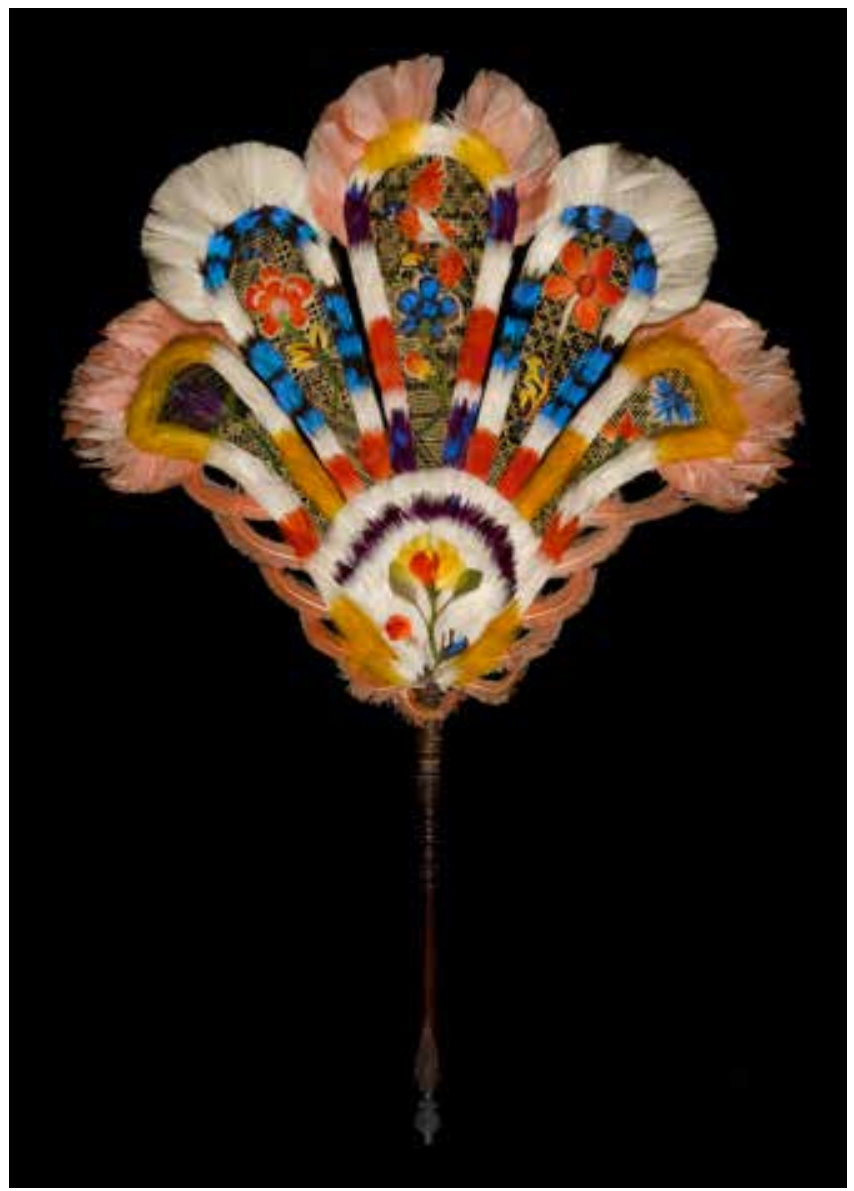

Figure 3.14: The Messel feather fan. South American and Dutch origin, ca. 1665. Feathers on woven panels, $340 \times 230$ mm. Cambridge, Fitzwilliam Museum, inv. no. M.358-1985. Image $\odot$ The Fitzwilliam Museum, Cambridge.

global artefacts, feather fans evoked associations of imperial treasures. It is no surprise that Francis Drake presented Elizabeth a fan comprising red and white feathers in 1587; she also holds a feather fan in the armada portrait, celebrating the Spanish defeat a year later. ${ }^{139}$ Similarly, the so-called Messel fan points to the global material trajectories of the Dutch Empire (Fig. 3.14). Produced in the late seventeenth century, the fan's mosaics are composed out of feathers that belonged to American species like the purple-breasted cotinga amabilis, found in the Dutch colonies of Brazil, the Guyanas, and Suriname. Finely cut feathers stitched onto woven panels, sometimes with a second layer of glued feathers, show scenes of 
exotic flowers, birds, butterflies, and insects. ${ }^{140}$ Such intricate techniques of feather fan-making are dazzling, especially as they are proof of acts of material creativity in response to the first arrival of feather fans in Northern Europe from Italy in the $1530{ }^{141}$ According to Venetian inventories, feather-workers offered fans of different sizes, colours, and handles. In mid-sixteenth-century Milan, it was even "possible to buy paper templates for fans that could be cut out, coloured, used to hold feathers and then thrown away once they had disintegrated." ${ }^{142}$ Responding to the spread of techniques and tastes, Venetian feather-workers started to manufacture particularly small feathers into fans; a miniaturizing trend that also affected sixteenth-century Parisian featherworking. ${ }^{143}$

Both luxury and mass-produced feather fans captivated the senses - their visual effects can hardly be overestimated (Fig. 3.15a-b) - and it is this condition that relates the matter of feathers with bodies. Fast handling might have animated impressions of exotic fauna. The observation of a Württemberg visitor to the English court in 1595 is particularly important to bear in mind when discussing the relationship between feather fans, the body, and the senses: people used feather fans "to cool themselves." ${ }^{\prime 44}$ In a period that considered circulating air a crucial element of health regimes, French kings even awarded "new invention(s)" in fan-making with special privileges. ${ }^{145}$ In the visual culture of this period, precious cords or chains are seen to have tied fans to belts. Upon being detached, fans were elegantly held between the thumb and forefinger. When handled, feather fans partially un/covered the sleeves' lacework and distributed the scent of perfumed gloves, bracelets, and jewellery. ${ }^{146}$ Compared to panaches, the arrangement and handling of fans granted them a greater capacity to redistribute air and its sensory impressions. For providing feathers with scents and mastering this material's ability to extend pleasant olfactory experiences, French royal panache-makers and feather-workers maintained close contacts with glove-perfumers. ${ }^{147}$ Feathers' tantalizing scents complimented the seductive softness they maintained that generated erotic atmospheres; accordingly,

140 For a detailed discussion of the Messel Standing Feather Fan and the results from its analysis with imaging technology, see Hanß, "Material Creativity of Affective Artefacts in the Dutch Colonial World." 141 Hayward, Dress, $188 \mathrm{f}$.

142 Welch, "Art," 264f.; Agostino Carracci's sheet for fan-making, Milan, ca. 158o, etching, $369 \times 251$ mm, The British Museum, London (BM), Print \& Drawings, 1891,0713.652.

143 AN, MC/ET/III/308 (1558/01/28).

144 Arnold, Wardrobe, 132.

145 Sandra Cavallo and Tessa Storey, Healthy Living in Late Renaissance Italy (Oxford: Oxford University Press, 2013); AN, O/1/34, 350v.

146 Arnold, Wardrobe, 28-43; Evelyn Welch, "Scented Buttons and Perfumed Gloves: Smelling Things in Renaissance Italy," in Ornamentalism: The Art of Renaissance Accessories, ed. Bella Mirabella (Ann Arbor, MI: University of Michigan Press, 2011), 13-39.

147 AN, MC/ET/II/176 (1645/03/13-1645/04/05); Welch, "Buttons." 

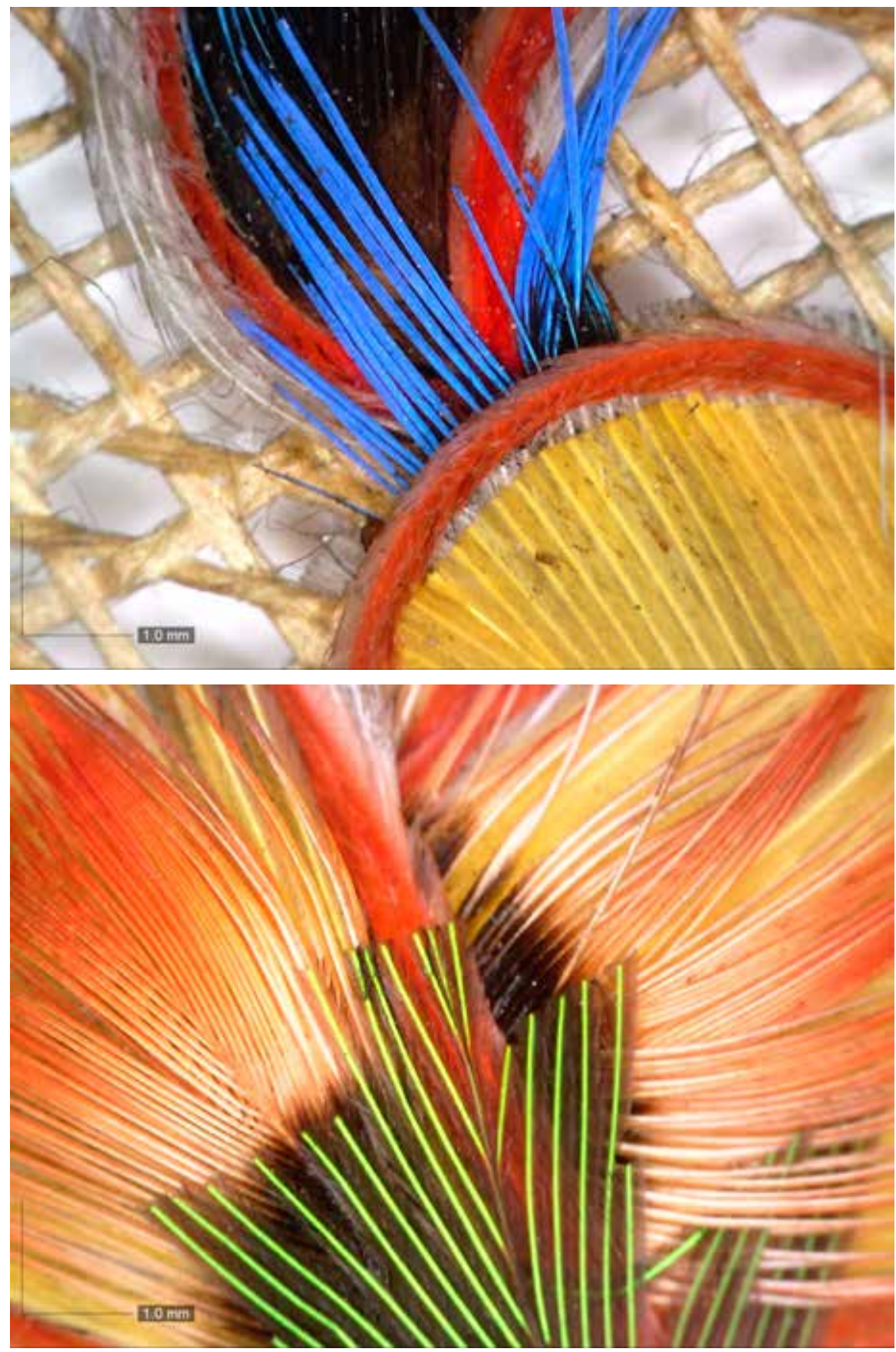

Figure 3.15a-b: The Messel feather fan. South American and Dutch origin, ca. 1665, detail of Fig. 3.14: Showing vibrantly coloured feather mosaics of flowers. Dino-Lite USB microscope AM7013MZT. Image (c) Stefan Hanß. 
fans were widely used to stage flirtations. ${ }^{148}$ Artisans enhanced such resonances through the application of liquids, heat, air, perfumes, dyestuffs, jewels, and the very arrangement and choice of feathers. On the one hand, feathers were starched to make them resistant to potential damage after rough handling. On the other hand, feather-workers deliberately crafted fans' softness by using several layers and, later on, altogether hundreds of feathers for panaches and fans. In the 1550s, Parisian feather-worker Thomas Flache surely decided to process the feathers of cranes due to their very material characteristics: their solid lower parts made crane feathers easy to fix to handles and guaranteed the feathers' stability while being handled; the feathers' upper part with their defined barbs, however, is of downy appearance, which attracts tactile engagement. ${ }^{149}$ Through their expertise in making, feather-workers extended and instantiated sensorial experiences. These artisans' skills crafted objects whose material properties - through interaction with bodily movements - enacted affective fields, shaped sensorial engagement, and stimulated emotional responses. Feather-workers helped crafting materialized identities.

\section{Crafting Affective Matter}

This chapter charted the hitherto unknown history of early modern European artisans who specialized in trading, processing, and manufacturing feathers. Archaeologists' theoretical approaches to material culture and their attunement to questions of material affordances, sensorialities, material engagement, and assemblage theory, I argued, are particularly useful to discuss the vibrancy of early modern featherwork. As globally traded commodities, feathers shaped commerce and consumption by generating styles and desires. They caused economic entrepreneurship that manifested in the formation of specialized guilds, female industriousness, supra-regional networks, and craft specialization. Such developments further stimulated cultures of tastes by making a huge spectrum of featherwork available for a diversified market of knowledgeable buyers in cities and courts alike. In that sense, early modern featherworking and feather-trading commerce has to be considered both a result and a driving force of the global consumerism that responded to materials' striking properties and thereby transformed material and aesthetic lives in early modern Europe..$^{150}$

This observation should lead to a reconsideration of the cross-cultural dynamics of the material Renaissance. Thus far, historians have addressed the artisanship of 
New World featherwork on the one hand and their collection in sixteenth-century Europe on the other. ${ }^{151}$ This approach constructs a cultural dichotomy between indigenous production/ritual usage versus European perception/representation. ${ }^{152}$ By exploring the unknown material worlds of Dutch, English, French, German, Italian, and Spanish feather-workers, this chapter questions the traditional story of Europeans' passive perception of American featherwork. An object-centred approach is crucial to address European and non-European artefacts on the same analytical level: it charts a story of the flows of materials, things, and knowledge that connected early modern European artisans with the wider Atlantic, Mediterranean, and Asian worlds.

I studied featherworking in terms of artisans' material engagement - as the embodied making skills and cognitive knowledge of matter that lent featherwork cultural significance. Artisans' embeddedness within material assemblages with their own distinct affordances shaped the routines and innovations of early modern featherworking. The making of featherwork, understood as artisans' sensorial engagement with material transformation, aimed at the sensoriality of these objects: feather-workers transformed materials in such ways that allowed featherwork to foreground its culturally appreciated characteristics. It was precisely this material engagement that aimed at the enaction of aesthetics, as featherwork also called for certain modes of handling, bodily postures, and sensorial perceptions that were associated with emotional registers like flirtation, gallantry, or chivalry. By crafting featherwork in such ways, artisans positioned their products at the very heart of early modern affective fields: feather-workers made their artefacts efficacious agents that evoked affective resonances and provoked emotional responses.

\footnotetext{
$15^{1}$ Mariana Françozo, "Beyond the Kunstkammer: Brazilian Featherwork in Early Modern Europe," in Gerritsen and Riello, The Global Lives of Things, 105-127; Mary Norton, "Going to the Birds: Animals as Things and Beings in Early Modernity," in Early Modern Things: Objects and Their Histories, 1500-180o, ed. Paula Findlen (London and New York: Routledge, 2013), 53-83; Carina L. Johnson, Cultural Hierarchy in Sixteenth-Century Europe: The Ottomans and Mexicans (Cambridge: Cambridge University Press, 2011); Alessandra Russo, Gerhard Wolf, and Diana Fane, eds., Images Take Flight: Feather Art in Mexico and Europe, 1400-1700 (Munich: Hirmer, 2015).

152 Cf. Hanß, "Material Encounters.”
} 


\section{Bibliography}

\section{Unpublished Primary Sources}

Archivo General de Indias, Seville (AGI)

Audiencia de Santa Fe, 987, L.2

Indiferente General, 420, L.8

Archivo General de Palacio, Madrid (AGP)

Administración General, leg.5.260, exp.1

Sección de expedientes personales, caja 151, expediente 7

Archives Nationales Paris (AN)

$\mathrm{MC} / \mathrm{ET} / \mathrm{II} / 140,152$, 166, 176, 179, 183; III/12, 240/A-B, 308, 489; VIII/104, 316, 530, 564, 589 ,

593, 603, 632, 666; X/8; XI/109; XIX/158; XXII/52; XXIII/123, 477; XXIV/338, 342; XX-

$\mathrm{VII} / 457 ; \mathrm{XXIX/73}, 152 ; \mathrm{XXX} / 475 ; \mathrm{XXXIII} / 24 ; \mathrm{XXXIV/33;XLIII/173;} \mathrm{LXXIII/279;} \mathrm{LXXXIV/27;}$

$\mathrm{XCVIII} / 716 ; \mathrm{C} / 31 ; \mathrm{CV} / 587$

$\mathrm{MIC} / \mathrm{Y} / / 115$

$\mathrm{O} / 1 / 34$

Archivio di Stato di Torino, Turin (AST)

Commercio, mazzo 20 da ordin. cat. 4

Archivio di Stato di Venezia, Venice (ASVe)

Giudici di petizion, inventari di eredità, tutele, curatele, oppure richiesti in causa, b. $339 / 4$, n. $53 ; 340 / 5$, n. $55 ; 354 / 19$, n. $39 ; 360 / 25$, n. 79

Archives de la ville de Bruxelles/Archief van de Stad Brussel, Brussels (AVB/ASB)

Registre $\mathrm{n}^{\mathrm{o}} 3426$

Bibliothèque nationale de France, Paris $(\mathrm{BnF})$

ms. fr. 21798

The British Museum, London (BM)

Print \& Drawings, 1891,0713.652, Agostino Carracci, sheet for fan-making, Milan, ca. 1580. Etching, $369 \times 251 \mathrm{~mm}$

Print \& Drawings, E,8.114, Hans Schäufelein, The Wedding Dancers, ca. 1530s. Print, $263 \times 214 \mathrm{~mm}$

Châtelet de Paris

Y//10o, 127, 196 
Germanisches Nationalmuseum Nürnberg, Nuremberg (GNM)

Perg.-Urk.1587/05/05

T1593, 3784

Historisches Museum am Hohen Ufer, Hannover (HM)

L1435f

Landesarchiv Baden-Württemberg, Hauptstaatsarchiv Stuttgart (HStAS)

A 202, vol. 2394, Nr. 4, 5 r

A 256, vols. 81, 85, 86, 87, 89, 91, 93, 95, 96, 97, 107

Royal Collection Trust, UK (RC)

RCIN 913071, Henri Gissey, Louis XIV in the Guise of Apollo, no date (seventeenth century).

Graphite, watercolour, bodycolour, and gold paint on vellum, $304 \times 225 \mathrm{~mm}$

Stadsarchief Antwerpen (Felixarchief), Antwerp (SA)

$\mathrm{GA} \# 4254,77_{1150}$

Stadtarchiv Leipzig (StadtAL)

LXIV Nr. 46

Staatsarchiv Nürnberg (StAN)

B14/II Nr. 3

E1/1905, Nr. 1:Jornal vnd Schuldtbu[o]ch of Bartholomäus Viatis (1579); Nr. 18

Stadtarchiv Nürnberg, Nuremberg (StadtAN)

A1, Schwabach; 6, Nr. 691

B14/I, Nr. 57, 62, 68, 71, 90, 116, 133, 162, 181, 194; II, Nr. 13, 34, 36; III, Nr. 35

D1, Nr. 18,776

E1/1158, Nr. 1; 8, Nr. 2333/14, 17, 38; 17/II, Nr. 677; 18; 29/I, Nr. 397

F5, Nr. 2; $3 /$ I, III, V

GSI $5_{5}$ Obj.Nr. 58.725, 58.870, 59.300

$\mathrm{U}_{5} 6,58,61,64 \mathrm{af}$.

Stadt- und Staatsbibliothek Augsburg (SUSBA)

$2^{\circ} \operatorname{Cod} \mathrm{S} 68$

National Archives, Kew (TNA)

PROB 11/34/234, 11/104/348 


\section{Published Primary Sources}

Amman, Jost. Gynceceum, siue theatrvm mvliervm [...]. Frankfurt: Sigmund Feyerabend, 1586.

Bayle-Mouillard, Élisabeth-Félice. Manuel du fleuriste artificiel [...]. Paris: Roret, 1829.

Cennini, Cennino d'Andrea. "Il Libro dell'Arte": The Craftman's Handbook, translated by Daniel V. Thompson Jr. New York: Dover, 2016.

Diderot, Denis, and Jean B. d'Alembert, eds. Encyclopédie ou Dictionnaire raisonné des sciences, des arts et des métiers, vol. 2. Paris: Briasson et al., 1751.

Diderot, Denis, and Jean B. d'Alembert, eds. Encyclopédie ou Dictionnaire raisonné des sciences, des arts et des métiers, vol. 12. Paris: Samuel Fauche, 1765.

Diderot, Denis, and Jean B. d'Alembert, eds. Encyclopédie ou Dictionnaire raisonné des sciences, des arts et des métiers, vol. 8. Paris: Briasson et al., 1771.

Fugger, Wolfgang. Ein nutzlich vnd wolgegrundt Formular, Manncherlë̈ scho[e]ner schriefften [...]. Nuremberg: Valentin Geißler, 1553.

Hooke, Richard. Micrographia: or some Physiological Descriptions of Minute Bodies made by Magnifying Glasses with Observations and Inquiries thereupon. London: John Martyn, 1665.

Léry, Jean de. History of a Voyage to the Land of Brazil, otherwise called America, translated by Janet Whatley. Berkeley and Los Angeles, CA and Oxford: University of California Press, 1990.

Martyr, Peter (Pietro Martire d'Anghiera). De Orbe Novo Decades I-VIII, edited by Rosanna Mazzacane and Elisa Magoncalda. 2 vols. Genoa: Dipartimento di archeologia, filologia classica e loro tradizioni, 2005 .

Olina, Giovanni P. Vccelliera overo discorso della natvra, e proprieta di diversi vccelli [...]. Rome: Andrea Fei, 1622.

Weigel, Hans. Habitus prcecipvorvm popvlorum [...]. Nuremberg: Hans Weigel, 1577.

\section{Secondary Literature}

Arnold, Janet. Queen Elizabeth's Wardrobe Unlock'd: The Inventories of the Wardrobe of Robes prepared in July 1600 [...]. Leeds: British Library, 1988.

Bennett, Jane. Vibrant Matter: A Political Ecology of Things. Durham, NC and London: Duke University Press, 2010.

Bruna, Denis, ed. Fashioning the Body: An Intimate History of the Silhouette. New Haven, CT: Yale University Press, 2015.

Cavallo, Sandra, and Tessa Storey. Healthy Living in Late Renaissance Italy. Oxford: Oxford University Press, 2013.

David, Abraham. "Jewish Involvement in Ostrich Feathers Trade between Egypt and Venice in the 16th Century as Reflected in Documents from the Cairo Genizah." Judaica: Beiträge zum Verstehen des Judentums 74/1-2 (2018): 82-95. 
Eliason, Chad M., and Matthew D. Shawkey. "Decreased Hydrophobicity of Iridescent Feathers: A Potential Cost of Shiny Plumage." Journal of Experimental Biology 214 (2011): 2157-2163.

Emmendörffer, Christoph. "Wunde Welt: Hainhofers Diarium der schwedischen Besatzung Augsburgs." In Wunderwelt: Der Pommersche Kunstschrank, edited by Christoph Emmendörffer and Christof Trepesch, 466-539. Berlin and Munich: Deutscher Kunstverlag, 2014.

Epstein, Stephan R., and Maarten Prak, eds. Guilds, Innovation and the European Economy, 1400-1800. Cambridge: Cambridge University Press, 2009.

Findlen, Paula. “Afterword: How (Early Modern) Things Travel." In The Global Lives of Things: Material Culture of Connections in the Early Modern World, edited by Anne Gerritsen and Giorgio Riello, 241-246. London: Routledge, 2016.

Françozo, Mariana. "Beyond the Kunstkammer: Brazilian Featherwork in Early Modern Europe." In The Global Lives of Things: Material Culture of Connections in the Early Modern World, edited by Anne Gerritsen and Giorgio Riello, 105-127. London: Routledge, 2016.

Gayangos, Pascual de, ed. Cartas y relaciones de Hernan Cortés al Emperador Carlos V. Paris: Imprenta Central de los Ferro-Carriles, 1866.

Gerritsen, Anne, and Giorgio Riello. The Global Lives of Things: Material Culture of Connections in the Early Modern World. London: Routledge, 2016.

Gibson, James J. “The Theory of Affordances." In Perceiving, Acting, and Knowing: Toward an Ecological Psychology, edited by Robert E. Shaw, 127-137. Hillsdale, NJ: Erlbaum, 1977.

Gosden, Chris. "What Do Objects Want?" Journal of Archaeological Method and Theory 12, no. 3 (2005): 193-211.

Green, Nile. "Ostrich Eggs and Peacock Feathers: Sacred Objects as Cultural Exchange between Christianity and Islam." Al-Masāq 18 (2006): 27-66.

Hamilakis, Yannis. Archaeology of the Senses: Human Experience, Memory, and Affect. Cambridge: Cambridge University Press, 2013.

Hamilakis, Yannis, and Andrew M. Jones. “Archaeology and Assemblage.” Cambridge Archaeological Journal 27, no. 1 (2017): 77-84.

Hanß, Stefan. “Material Encounters: Knotting Cultures in Early Modern Peru and Spain.” The Historical Journal 62, no. 3 (2019): 583-615.

Hanß, Stefan. "New World Feathers and the Matter of Early Modern Ingenuity: Digital Microscopes, Period Hands, and Period Eyes." In Ingenuity in the Making: Materials and Technique in Early Modern Europe, edited by Alexander Marr, Richard Oosterhoff, and José Ramón Marcaida. Pittsburgh, PA: Pittsburgh University Press, 2021, in press.

Hanß, Stefan. Court and Material Culture in Early Modern Germany: A Sourcebook on the Duke of Württemberg's Payments to Artisans, Stuttgart, 1592-1628. Amsterdam: Amsterdam University Press, forthcoming. 
Hanß, Stefan. "The Material Creativity of Affective Artefacts in the Dutch Colonial World: Imaging and Imagining Early Modern Feather Fans." Current Anthropology (in press).

Hanß, Stefan. "Material Cross-Referencing in the Age of Courtly Consumption: Feathers and the Making of Luxury Experiences at the Early Modern Spanish Court" (forthcoming).

Hanß, Stefan, and Ulinka Rublack. "Knowledge Production, Image Networks, and the Material Significance of Feathers in Late Humanist Heidelberg." Renaissance Quarterly 74, no. 2 (2021): 1-39.

Harrap, B. S., and E. F. Woods. "Species Differences in the Proteins of Feathers." Comparative Biochemistry and Physiology 20 (1967): 449-460.

Harris, Oliver J. T., and Tim F. Sørensen. "Rethinking Emotion and Material Culture." Archaeological Dialogues 17, no. 2 (2010): 145-163.

Hayward, Maria. Dress at the Court of King Henry VIII: The Wardrobe Book of the Wardrobe of the Robes prepared by James Worsley in December 1516, edited from Harley MS 2284, and his Inventory prepared on 17 January 1521, edited from Harley $M S_{4217}$, both in the British Library. Leeds: Maney, 2007.

Hofmann, Cornelia. Das Federzimmer Augusts des Starken. Dresden: Verlag der Kunst, 2003. Horie, C. V. "Fading of Feathers by Light." In gth Triennial Meeting, Dresden, German Democratic Republic, 26-31 August 199o, edited by International Council of Museums Conservation Committee, 431-436. Los Angeles, CA: International Council of Museums Conservation Committee, 1990.

Jegel, August, ed. Alt-Nürnberger Handwerksrecht und seine Beziehungen zu anderen. Nürnberg-Reichelsdorf: Schmidt, 1965 .

Johnson, Carina L. Cultural Hierarchy in Sixteenth-Century Europe: The Ottomans and Mexicans. Cambridge: Cambridge University Press, 2011.

Kushlan, James A., and James A. Hancock. The Herons. Oxford: Oxford University Press, 2005. Lehmann, Ann-Sophie. "The Matter of the Medium: Some Tools for an Art Theoretical Interpretation of Materials." In The Matter of Art: Materials, Technologies, Meanings, 1200-170o, edited by Christy Anderson, Anne Dunlop, and Pamela H. Smith, 21-41. Manchester: Manchester University Press, 2014.

Lemire, Beverly. Global Trade and the Transformation of Consumer Cultures: The Material World Remade, c. 1500-1820. Cambridge: Cambridge University Press, 2018.

Lieb, Norbert. Octavian Secundus Fugger (1549-16oo) und die Kunst. Tübingen: Mohr, 1980.

Malafouris, Lambros. How Things Shape the Mind: A Theory of Material Engagement. Cambridge, MA and London: MIT Press, 2013.

Marcaida López, José Ramón. “El ave del paraíso: historia natural y alegoría." In Alegorías: imagen y discurso en la España Moderna, edited by María Tausiet, 93-108. Madrid: Consejo Superior de Investigaciones Científicas, 2014.

Marín-Aguilera, Beatriz. “(De)Orientalising Spain: The 'Other’ from Within.” Arkeogazte 6 (2016): $75^{-89}$. 
Marín-Aguilera, Beatriz. "Inhabiting Domestic Space: Becoming Different in the Early Iron Age Western Mediterranean." Journal of Mediterranean Archaeology 31, no. 1 (2018): 77-100.

Norton, Mary. "Going to the Birds: Animals as Things and Beings in Early Modernity." In Early Modern Things: Objects and Their Histories, 1500-1800, edited by Paula Findlen, 53-83. London and New York: Routledge, 2013.

O'Malley, Michelle, and Evelyn S. Welch, eds. The Material Renaissance. Manchester: Manchester University Press, 2007.

Reckwitz, Andreas. "Affective Spaces: A Praxeological Outlook." Rethinking History 16, no. 2 (2012): 241-258.

Rosenbaum, David A. Knowing Hands: The Cognitive Psychology of Manual Control. Cambridge: Cambridge University Press, 2017.

Rublack, Ulinka. "Matter in the Material Renaissance." Past and Present 219 (2013): 41-85.

Rublack, Ulinka. "Renaissance Dress, Cultures of Making, and the Period Eye." West 86th: AJournal of Decorative Arts, Design History, and Material Culture 23 (2016): 6-34.

Rublack, Ulinka. "Befeathering the European: The Matter of Feathers in the Material Renaissance.” The American Historical Review 126, no. 1 (March 2021): 19-53, https:// doi.org/10.1093/ahr/rhaboo6.

Russo, Alessandra. The Untranslatable Image: A Mestizo History of the Arts in New Spain, 1500-160o. Austin, TX: University of Texas Press, 2014.

Russo, Alessandra, Gerhard Wolf, and Diana Fane, eds. Images Take Flight: Feather Art in Mexico and Europe, 1400-170o. Munich: Hirmer, 2015.

Seibold, Gerhard. Die Viatis und Peller: Beiträge zur Geschichte ihrer Handelsgesellschaft. Cologne: Böhlau, 1977.

Smith, Pamela H. The Body of the Artisan: Art and Experience in the Scientific Revolution. Chicago, IL: University of Chicago Press, 2004.

Smith, Pamela H., and Tonny Beentjes. "Nature and Art, Making and Knowing: Reconstructing Sixteenth-Century Life-Casting Techniques." Renaissance Quarterly 63 (2010): 128-179.

Swan, Claudia. "Exotica on the Move: Birds of Paradise in Early Modern Holland." Art History 38, no. 4 (2015): 621-635.

Vlček, Pavel et al., eds. Umělecké památky Prahy, vol. 3. Prague: Academia, 1999.

Von Rohr, Alheidis. "Kleidung eines Patriziers aus Einbeck vom Ende des 16. Jahrhunderts." Waffen- und Kostümkunde 18 (1976): 69-75.

Welch, Evelyn. "Art on the Edge: Hair and Hands in Renaissance Italy." Renaissance Studies 23, no. 3 (2009): 241-268.

Welch, Evelyn. "Scented Buttons and Perfumed Gloves: Smelling Things in Renaissance Italy." In Ornamentalism: The Art of Renaissance Accessories, edited by Bella Mirabella, 13-39. Ann Arbor, MI: University of Michigan Press, 2011.

Zander-Seidel, Jutta. Textiler Hausrat: Kleidung und Haustextilien in Nürnberg von 1500-1650. Munich: Deutscher Kunstverlag, 1990. 
Zander-Seidel, Jutta, ed. In Mode: Kleider und Bilder aus Renaissance und Frühbarock. Nuremberg: Germanisches Nationalmuseum, 2015.

Zimmermann, Heinrich. "Das Inventar der Prager Schatz- und Kunstkammer vom 6. Dezember 1621: nach Akten des K. und K. Reichsfinanzarchives in Wien.” Kunsthistorische Sammlungen des Allerhöchsten Kaiserhauses 25 (1905): XIII-LXXV.

\section{About the Author}

Stefan Hanß is Senior Lecturer at The University of Manchester. His research focuses on early modern material culture and cultural encounters. Current projects cover the history of early modern hair and featherworking. Hanß has been awarded a British Academy Rising Star Engagement Award and a Philip Leverhulme Prize. 
